\title{
Assessing the Methods, Tools, and Statistical Approaches in Google Trends Research: Systematic Review
}

Amaryllis Mavragani ${ }^{1}$, BSc, MSc; Gabriela Ochoa ${ }^{1}$, BSc, MSc, PhD; Konstantinos P Tsagarakis ${ }^{2}$, DipEng, PhD

${ }^{1}$ Department of Computing Science and Mathematics, University of Stirling, Stirling, Scotland, United Kingdom

${ }^{2}$ Department of Environmental Engineering, Democritus University of Thrace, Xanthi, Greece

\section{Corresponding Author:}

Amaryllis Mavragani, BSc, MSc

Department of Computing Science and Mathematics

University of Stirling

Stirling, Scotland, FK94LA,

United Kingdom

Phone: 447523782711

Email: amaryllis.mavragani1@stir.ac.uk

\section{Abstract}

Background: In the era of information overload, are big data analytics the answer to access and better manage available knowledge? Over the last decade, the use of Web-based data in public health issues, that is, infodemiology, has been proven useful in assessing various aspects of human behavior. Google Trends is the most popular tool to gather such information, and it has been used in several topics up to this point, with health and medicine being the most focused subject. Web-based behavior is monitored and analyzed in order to examine actual human behavior so as to predict, better assess, and even prevent health-related issues that constantly arise in everyday life.

Objective: This systematic review aimed at reporting and further presenting and analyzing the methods, tools, and statistical approaches for Google Trends (infodemiology) studies in health-related topics from 2006 to 2016 to provide an overview of the usefulness of said tool and be a point of reference for future research on the subject.

Methods: Following the Preferred Reporting Items for Systematic Reviews and Meta-Analyses guidelines for selecting studies, we searched for the term "Google Trends" in the Scopus and PubMed databases from 2006 to 2016, applying specific criteria for types of publications and topics. A total of 109 published papers were extracted, excluding duplicates and those that did not fall inside the topics of health and medicine or the selected article types. We then further categorized the published papers according to their methodological approach, namely, visualization, seasonality, correlations, forecasting, and modeling.

Results: All the examined papers comprised, by definition, time series analysis, and all but two included data visualization. A total of $23.1 \%$ (24/104) studies used Google Trends data for examining seasonality, while 39.4\% (41/104) and 32.7\% (34/104) of the studies used correlations and modeling, respectively. Only 8.7\% (9/104) of the studies used Google Trends data for predictions and forecasting in health-related topics; therefore, it is evident that a gap exists in forecasting using Google Trends data.

Conclusions: The monitoring of online queries can provide insight into human behavior, as this field is significantly and continuously growing and will be proven more than valuable in the future for assessing behavioral changes and providing ground for research using data that could not have been accessed otherwise.

(J Med Internet Res 2018;20(11):e270) doi: 10.2196/jmir.9366

\section{KEYWORDS}

big data; health assessment; infodemiology; Google Trends; medicine; review; statistical analysis

\section{Introduction}

Big data are characterized by the 8 Vs [1]: volume (exponentially increasing volumes) [2], variety (wide range of datasets), velocity (high processing speed) [3], veracity, value
[4,5], variability, volatility, and validity [1]. Big data have shown great potential in forecasting and better decision making [1]; though handling these data with conventional ways is inadequate [6], they are being continuously integrated in research [7] with novel approaches and methods. 
The analysis of online search queries has been of notable popularity in the field of big data analytics in academic research [8,9]. As internet penetration is continuously increasing, the use of search traffic data, social media data, and data from other Web-based sources and tools can assist in facilitating a better understanding and analysis of Web-based behavior and behavioral changes [10].

The most popular tool for analyzing behavior using Web-based data is Google Trends [11]. Online search traffic data have been suggested to be a good analyzer of internet behavior, while Google Trends acts as a reliable tool in predicting changes in human behavior; subject to careful selection of the searched-for terms, Google data can accurately measure the public's interest [12]. Google Trends provides the field of big data with new opportunities, as it has been shown to be valid [13] and has been proven valuable [14,15], accurate [16], and beneficial [17] for forecasting. Therefore, great potential arises from using Web-based queries to examine topics and issues that would have been difficult or even impossible to explore without the use of big data. The monitoring of Web-based activity is a valid indicator of public behavior, and it has been effectively used in predictions [18,19], nowcastings [20], and forecasting $[17,21,22]$.

Google Trends shows the changes in online interest for time series in any selected term in any country or region over a selected time period, for example, a specific year, several years, 3 weeks, 4 months, 30 days, 7 days, 4 hours, 1 hour, or a specified time-frame. In addition, different terms in different regions can be compared simultaneously. Data are downloaded from the Web in ".csv" format and are adjusted as follows: "Search results are proportionate to the time and location of a query: Each data point is divided by the total searches of the geography and time range it represents, to compare relative popularity. Otherwise places with the most search volume would always be ranked highest. The resulting numbers are then scaled on a range of 0 to 100 based on a topic's proportion to all searches on all topics. Different regions that show the same number of searches for a term will not always have the same total search volumes" [23].

Healthcare is one of the fields in which big data are widely applied [24,25], with the number of publications in this field showing a high increase [26]. Researchers have placed a significant focus on examining Web-based search queries for health and medicine related topics [27]. Data from Google Trends have been shown to be valuable in predictions, detection of outbreaks, and monitoring interest, as detailed below, while such applications could be analyzed and evaluated by government officials and policy makers to deal with various health issues and disease occurrence.

The monitoring and analysis of internet data fall under the research field of infodemiology, that is, employing data collected from Web-based sources aiming at informing public health and policy [28]. These data have the advantage of being real time, thus tackling the issue of long periods of delay from gathering data to analysis and forecasting. Over the past decade, the field of infodemiology has been shown to be highly valuable in assessing health topics, retrieving web-based data from, for example, Google [29,30], Twitter [31-34], social media [35,36], or combinations of $\geq 2$ Web-based data sources [37,38].

As the use of Google Trends in examining human behavior is relatively novel, new methods of assessing Google health data are constantly arising. Up to this point, several topics have been examined, such as epilepsy $[39,40]$, cancer [41], thrombosis [42], silicosis [43], and various medical procedures including cancer screening examinations [44,45], bariatric surgery [46], and laser eye surgery [47].

Another trend rising is the measurement of the change in interest in controversial issues $[48,49]$ and in drug-related subjects, such as searches in prescription [50] or illicit drugs [51,52]. In addition, Google Trends data have been used in examining interest in various aspects of the health care system [53-55].

Apart from the above, Google Trends data have also been useful in measuring the public's reaction to various outbreaks or incidents, such as attention to the epidemic of Middle East Respiratory Syndrome [56], the Ebola outbreak [57], measles [58], and Swine flu [59], as well as the influence of media coverage on online interest [60]. Google queries for the respective terms have been reported to increase or peak when a public figure or celebrity is related [61-65].

Google Trends has also been valuable in examining seasonal trends in various diseases and health issues, such as Lyme disease [66], urinary tract infection [67], asthma [30], varicose vein treatment [68], and snoring and sleep apnea [69]. Furthermore, Deiner et al [70] showed that indeed there exists the same seasonality in Google Trends and clinical diagnoses. What has also been reported is that seasonality in Google searches on tobacco is correlated with seasonality in Google searches on lung cancer [71], while online queries for allergic rhinitis have the same seasonality as in real life cases [72]. Thus, we observe that, apart from measuring public interest, Google Trends studies show that the seasonality of online search traffic data can be related to the seasonality of actual cases of the respective diseases searched for.

As mentioned above, Google queries have been used so far to examine general interest in drugs. Taking a step further, Schuster et al [73] found a correlation between the percentage change in the global revenues in Lipitor statin for dyslipidemia treatment and Google searches, while several other studies have reported findings toward this direction, that is, correlations of Web-based searches with prescription issuing [74-76]. The detection and monitoring of flu has also been of notable popularity in health assessment. Data from Google Flu Trends have been shown to correlate with official flu data [77,78], and Google data on the relevant terms correlate with cases of influenza-like illness [79].

In addition, online search queries for suicide have been shown to be associated with actual suicide rates [80,81], while other examples indicative of the relationship between Web-based data and human behavior include the correlations between official data and internet searches in veterinary issues [82], sleep deprivation [83], sexually transmitted infections [84], Ebola-related searches [85], and allergies [86,87].

Furthermore, Zhou et al [88] showed how the early detection of tuberculosis outbreaks can be improved using Google Trends 
data; while suicide rates and Google data seem to be related, the former are suggested to be a good indicator for developing suicide prevention policies [89]. In addition, methamphetamine criminal behavior has been shown to be related to meth searches [90]. Finally, recent research on using Google Trends in predictions and forecasting include the development of predictive models of pertussis occurrence [91], while online search queries have been employed to forecast dementia incidence [92] and prescription volumes in ototopical antibiotics [93].

Given the diversity of subjects that Google Trends data have been used up for until this point to examine changes in interest and the usefulness of this tool in assessing human behavior, it is evident that the analysis of online search traffic data is indeed valuable in exploring and predicting behavioral changes.

In 2014, Nuti et al [27] published a systematic review of Google Trends research including the years up to 2013. This review was of importance as the first one in the field, and it reported Google Trends research up to that point. The current review differs from Nuti et al's in two ways. First, it includes 3 more full years of Google Trends research, that is, 2014, 2015, and 2016, which account for the vast majority of the research conducted in this field for the examined period based on our selection criteria. Second, while the first part of our paper is a systematic review reporting standard information, that is, authors, country, region, keywords, and language, the second part offers a detailed analysis and categorization of the methods, approaches, and statistical tools used in each of this paper. Thus, it serves as a point of reference in Google Trends research not only by subject or topic but by analysis or method as well.

\section{Methods}

The aim of this review was to include all articles on the topics of health and medicine that have used Google Trends data since its establishment in 2006 through 2016. We searched for the term "Google Trends" in the Scopus [94] and PubMed [95] databases from 2006 to 2016, and following the Preferred Reporting Items for Systematic Reviews and Meta-Analyses guidelines (Figure 1), the total number of publications included in this review was 109 . 
Figure 1. Preferred Reporting Items for Systematic Reviews and Meta-Analyses flow diagram of the selection procedure for including studies.
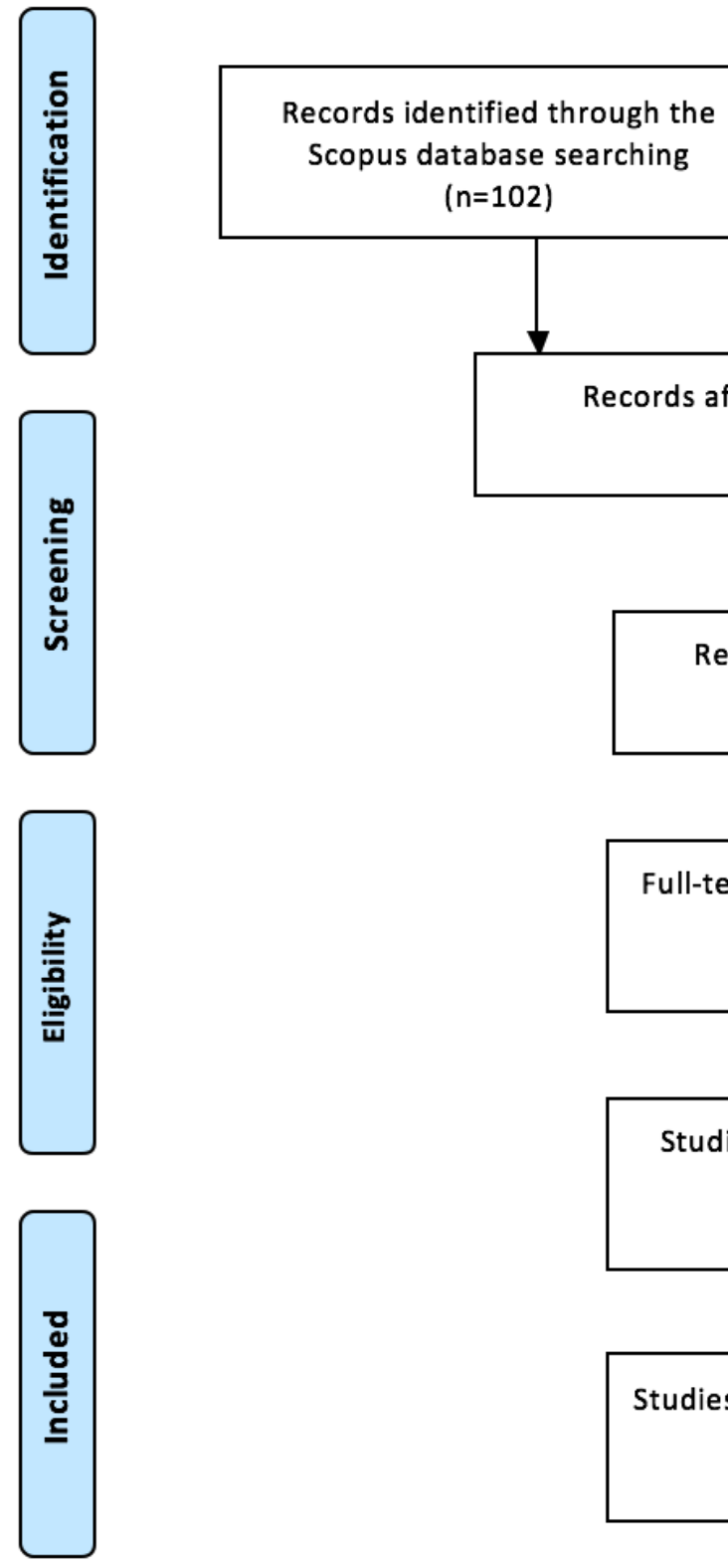
$(n=102)$

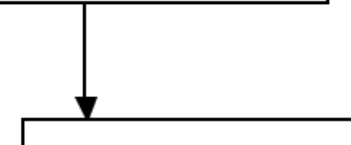

Records identified through the

PubMed database searching

$(n=141)$

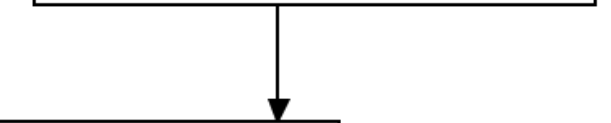

Records after duplicates removed

$(n=159)$
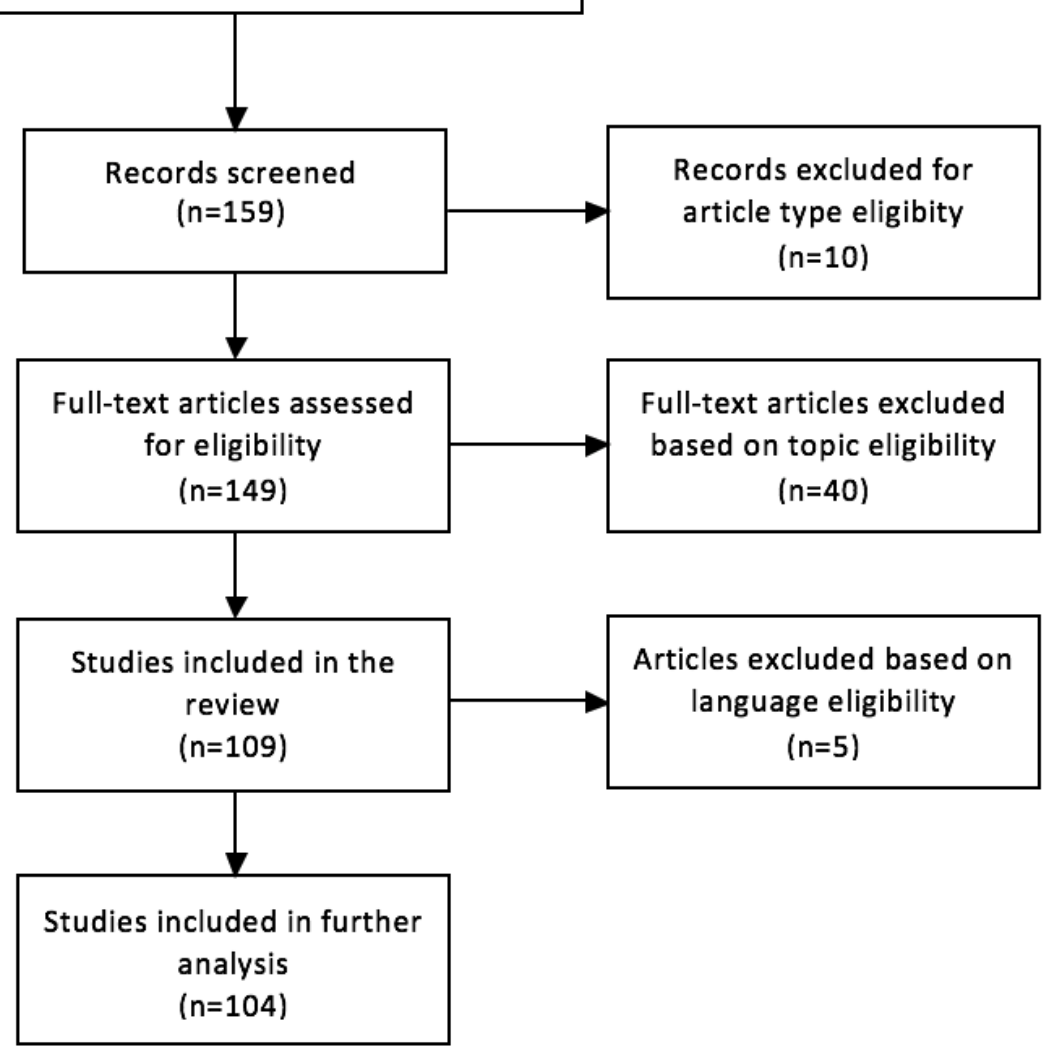

First, we conducted a search in Scopus for the keyword "Google Trends" in the "Abstract-Title-Keywords" field for "Articles," "Articles in press," "Reviews," and "Conference papers" from 2006 to 2016. Out of the available categories, we selected "Medicine," "Biochemistry Genetics and Molecular Biology," "Neuroscience," "Immunology and Microbiology," "Pharmacology, Toxicology, and Pharmaceuticals," "Health Profession," "Nursing," and "Veterinary." The search returned 102 publications. Second, we searched for the keyword "Google Trends" in PubMed from 2006 to 2016, which provided a total of 141 publications. Excluding the duplicates, which numbered 84 in total, 159 publications met our criteria. Excluding the ones that did not match the criteria for article type (10 publications) and the ones that did not fall inside the scope of health and medicine (40 publications), a total of 109 studies were included in this review. Note that 5 studies were written in a language other than English and were therefore not included in the

quantitative part or in the detailed analysis of the methods of each study. Figure 2 depicts the number of publications by year from 2009 to 2016: 2 in 2009, 3 in 2010, 2 in 2011, 1 in 2012, 12 in 2013, 21 in 2014, 28 in 2015, and 40 in 2016.

The selected studies are further analyzed according to their methodologies, and the gaps, advantages, and limitations of the tool have been discussed so as to assist in future research. Thus, we provide a more detailed categorization of the examined papers according to the main category that they belong to, that is, visualization and general time series analysis, seasonality, correlations, predictions or forecasting, modeling, and statistical method or tool employed. Note that a study can fall into $>1$ category. The categorization by individual medical field is not applicable due to the high number of individual topics. Table 1 consists of the description of each parameter used to classify each study. 
Figure 2. Google Trends' publications per year in health-related fields from 2009 to 2016.

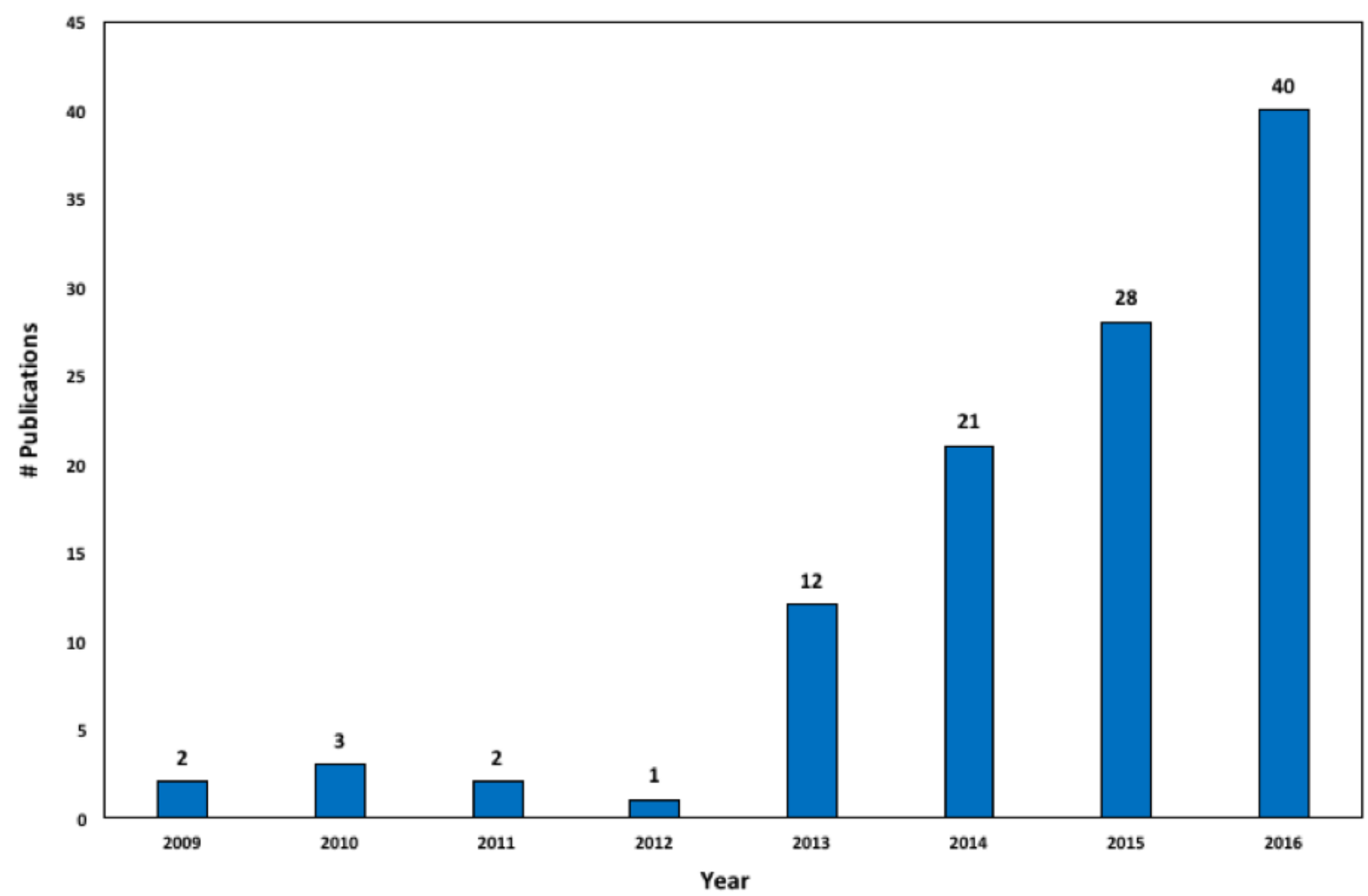

Table 1. Description of the parameters used for classification.

\begin{tabular}{|c|c|}
\hline Parameter & Description \\
\hline Authors & Includes the surname of the authors, date of publication, and link to the reference list (eg, Smith et al, 2016 [57]). \\
\hline Period & Refers to the time-frame for which Google Trends data were retrieved and used in the study (eg, 2004-2015). \\
\hline Region & Refers to the country or countries or region (eg, USA; Worldwide; Oceania) that Google Trends data were extracted for. \\
\hline Language & Refers to the language in which the Google Trends search was conducted (eg, search for the Italian word $\mathrm{Si}$ ). \\
\hline Keywords & $\begin{array}{l}\text { Basic keywords are included in this category, mostly referring to the health topic examined and important keywords used to } \\
\text { describe it. }\end{array}$ \\
\hline Visualization (V) & Includes any form of visualization, that is, figures, maps, and screenshots (eg, screenshots of the Google Trends website). \\
\hline Seasonality (S) & Studies that have explored the seasonality of the respective topic are included. \\
\hline Correlations (C) & $\begin{array}{l}\text { Studies that have examined correlations are included in this category. Correlations may be between Google Trends data and } \\
\text { official data, among Google Trends time series, or between Google Trends and other Web-based sources' time series. }\end{array}$ \\
\hline Forecasting $(\mathrm{F})$ & $\begin{array}{l}\text { This category includes studies that conducted forecasting of either Google Trends time series or diseases, outbreaks, etc, using } \\
\text { Google Trends data, independent of the method used. }\end{array}$ \\
\hline Modeling (M) & Studies in this category conducted some form of modeling using Google Trends data. \\
\hline Statistical Tools (St) & $\begin{array}{l}\text { This category includes the studies that used statistical tools or tests, eg, } t \text { test. Tools and methods for statistical modeling, (eg, } \\
\text { regression), are not included in this category but only in the category of Modeling. }\end{array}$ \\
\hline
\end{tabular}




\section{Results}

Multimedia Appendix 1 consists of the first classification of the selected studies [27,39-57,59-93,96-144]; there are 104 in total, as the studies of Kohler et al [145], Orellano et al [146], Cjuno et al [147], Tejada-Llacsa [148], and Yang et al [149] are written in German, Spanish, or Chinese, and thus are not included in the more detailed categorization and analysis.

All the examined papers involve, by definition, time series analysis, and almost all include some form of visualization. Only $8.7 \%$ (9/104) studies used Google Trends data for predictions and forecasting, and $23.1 \%$ (24/104) used them for examining seasonality, while correlations and modeling were performed in 39.4\% (41/104) and 32.7\% (34/104) studies, respectively. As the category of forecasting and predictions exhibits the least number of studies, it is evident that a gap exists in the literature for forecasting using Google Trends in health assessment.

As is evident in Multimedia Appendix 1, Google queries have been employed up to this point in many countries and several languages. Figure 3 shows a worldwide map by examined country for assessing health and medicine related issues using Google Trends data up to 2016. Worldwide, the studies that explore topics related to the respective terms number 23 in total. As far as individual countries are concerned, US data have been employed in the most (60) studies, while other countries that have been significantly examined include the United Kingdom (15), Australia (13), Canada (9), Germany (8), and Italy (7).

The four most examined countries are English-speaking ones. The reasons for this could include that Google Trends, though not case-sensitive, does take into account accents and spelling mistakes; therefore, for countries with more complicated alphabets, the analysis of Web-based data should be more careful. In addition, other factors that could play a significant role and are taken into account when choosing the countries to be examined using online search traffic data are the availability of official data, the openness of said data, any internet restrictions or monitoring in countries with lower scores in freedom of press or freedom of speech, and internet penetration.

The rest of the analysis consists of the further breaking down of the initial categorization to include the respective methods that were used for examining seasonality, correlations, forecasting, and performing statistical tests and estimating models, along with a concise introduction to each of these methods and how they were used to assess health issues.

Table 2 shows the methods used to explore seasonality; Tables 3 and 4 present the methods used to examine correlations and perform predictions and forecasting, respectively. Finally, Tables 5 and 6 list the modeling methods and other statistical tools employed in health assessment using Google Trends.

The most popular way to explore seasonality is to use visual evidence and examine and discuss peaks, as shown in Table 2. Furthermore, several studies have used cosinor analysis $[8,69,134,138,142]$, which is a time series analysis method for seasonal data using least squares.

Apart from seasonality [122], analysis of variance (ANOVA) has been also used for geographical comparisons between regions or countries $[49,51,68,93]$ and between differences in monthly data [41]. It is a test used for examining if significant differences between means exist. In the case of 2 means, $t$ test is the equivalent to ANOVA.

The Kruskal-Wallis test is also a popular method for examining seasonality using Google Trends [57,68,113]. It is a nonparametric, independent of distribution test, for continuous as well as ordinal-level dependent variables, employed when the one-way ANOVA assumptions do not hold, that is, for examining statistically significant differences between $\geq 3$ groups. It uses random sample with independent observations, with the dependent variable being at least ordinal.

Figure 3. Countries by number of Scopus and PubMed publications using Google Trends.

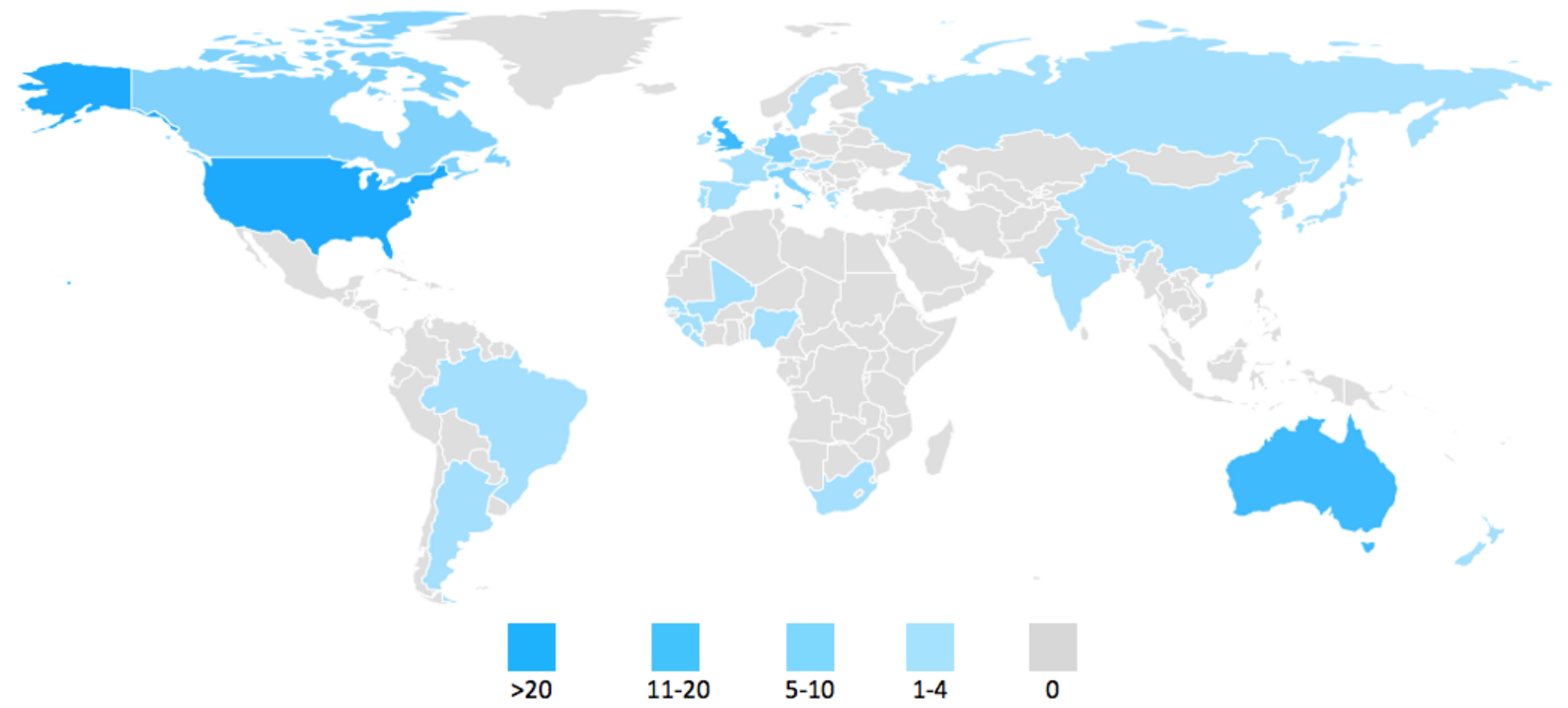


Other methods of exploring seasonality include the nonparametric tests (independent of distribution) Wilcoxon signed rank [18,113] and Mann-Whitney U test [67], which are used for comparing data in different seasons or time periods when the equivalent parametric $t$ tests cannot be used. The latter has been also used by some studies to compare weekly data [105] and differences among regions [113].

For examining correlations (Table 3), the vast majority of the studies used the Pearson correlation coefficient, which examines the strength of association between 2 quantitative, continuous variables, employed when the relationship is linear. The Spearman rho (rank-order) correlation, the second most used method, is the nonparametric version of the Pearson correlation, has also been used to explore seasonality between time series [70]. Spearman correlation coefficient (denoted by $\rho$ or $r_{s}$ ) measures the levels to which 2 ranked variables (ordinal, interval, or ratio) are related to each other.

Cross-correlations are used for examining the relationship of 2 time series, while simultaneously exploring if the data are periodic. It is often employed in correlating Google Trends data with observed data $[50,82,90,135]$ and between different Google search terms [80], while it can be also used for examining linear and temporal associations of seasonal data [71]. Cross-correlations have been also used in forecasting, where Wang et al [92] showed that cross-correlations of new dementia cases with Google Trends data can assist with the forecasting of dementia cases, and Solano et al [80] forecasted the suicide rates 2 years ahead using Google queries. The autocorrelations are basically cross-correlations for one time series, that is, a time series cross-correlated with itself.

The Kendall's tau-b test correlation coefficient is a nonparametric alternative to Pearson and Spearman correlations and is used to measure the strength and direction of the relationship between 2 (at least ordinal) variables. It has been employed by 1 study [138] to examine the correlations between Google Trends data and the results of a paper interview survey.
The Spearman-Brown prediction (or prophecy) formula is used to predict how reliable the test is after changing its length. It has also been employed by only 1 study [65] to explore the relationship between railway suicide and Google hits.

The generalized linear model estimates the linear relationship between a dependent and $\geq 1$ independent variables. It was used by Domnich et al [79] to predict influenza-like illness morbidity, with the exploratory variables being "Influenza," "Fever," and "Tachipirin search volumes," along with the Holt-Winters method and the autoregressive moving average process for the residuals. Holt-Winters is a method employed in exploring the seasonality in time series, and for predictions, the autoregressive moving average (also called the Box-Jenkins model) is a special case of the autoregressive integrated moving average, used for the analysis of time series and predictions.

Autoregressive integrated moving average is a commonly used method for time series analysis and predictions $[55,63,86,92,141]$, the latter having also been assessed by linear regressions and modeling [88,91]. Multivariable regressions are used to estimate the relationship of $\geq 2$ independent variables with a dependent one. In Google Trends, they have been used to relate Ebola searches, reported cases, and the Human Development Index [85] and to study the relationship between climate and environmental variables and Google hits [125].

Hierarchical linear modeling is a regression of ordinary least squares that is employed to analyze hierarchically structured data, that is, units that are grouped together, and it has been employed by 1 study so far [83].

The Mann-Kendall test, which is the nonparametric alternative test to the independent sample, has been used to show the statistical differences of peaks [43] and to detect trends [140]. Finally, the $t$ test is used to compare 2 sample means of the same population, and it has been employed for comparing Google searches with the baseline period [105] and to examine the statistical differences of peaks [41]. 
Table 2. Methods for exploring seasonality with Google Trends in health assessment.

\begin{tabular}{|c|c|c|c|}
\hline Number & Authors & Method & Description \\
\hline 1 & Bakker et al, 2016 [96] & Morlet Wavelet Analysis & $\begin{array}{l}\text { To test the seasonality of Google Trends data in the examined } \\
\text { countries }\end{array}$ \\
\hline 2 & Braun and Harreus, 2013 [104] & Visual evidence & $\mathrm{N} / \mathrm{A}^{\mathrm{a}}$ \\
\hline 3 & Crowson et al, 2016 [93] & Seasonal peaks & N/A \\
\hline 4 & Deiner et al, 2016 [70] & Spearman correlation & $\begin{array}{l}\text { Correlating the seasonality of clinical diagnoses with Google } \\
\text { Trends data }\end{array}$ \\
\hline 5 & El-Sheikha, 2015 [113] & Kruskal-Wallis test & To show seasonality for different months \\
\hline 6 & Garrison et al, 2015 [116] & Least-squares sinusoidal model & $\begin{array}{l}\text { Variability in outcomes (supported also from a comparison } \\
\text { with searches in Australia) }\end{array}$ \\
\hline 7 & Harsha et al, 2014 [68] & Kruskal-Wallis test & Seasonal (monthly) comparisons \\
\hline 8 & Harsha et al, 2015 [119] & Kruskal-Wallis test & Seasonal (monthly) comparisons \\
\hline 9 & Hassid et al, 2016 [120] & Pearson correlation & To examine seasonal variations across symptoms \\
\hline 10 & Ingram and Plante, 2013 [122] & Cosinor analysis; analysis of variance & $\begin{array}{l}\text { To test the seasonal variation of the normalized Google Trends } \\
\text { data; to compare the seasonal increase among the examined } \\
\text { countries }\end{array}$ \\
\hline 11 & Ingram et al, 2015 [69] & Cosinor analysis & $\begin{array}{l}\text { To test the seasonal variation of the normalized Google Trends } \\
\text { data }\end{array}$ \\
\hline 12 & Kang et al, 2015 [72] & Visual observation & N/A \\
\hline 13 & Leffler et al, 2010 [125] & Correlations & $\begin{array}{l}\text { Showing correlations among the } 4 \text { seasons for the } 39 \text { examined } \\
\text { terms }\end{array}$ \\
\hline 14 & Liu et al, 2016 [127] & Seasonal model and a null model & $\begin{array}{l}\text { Seasonality explained the searches significantly better with } \\
\text { an F-test }\end{array}$ \\
\hline 15 & Phelan et al, 2016 [133] & Correlograms (autocorrelations plots) & Visual interpretation for exploring seasonal peaks \\
\hline 16 & Plante and Ingram, 2014 [134] & Cosinor analysis & $\begin{array}{l}\text { To test the seasonal variation of the normalized Google Trends } \\
\text { data }\end{array}$ \\
\hline 17 & Rossignol et al, 2013 [67] & $\begin{array}{l}\text { Mann-Whitney U test; Harmonic } \\
\text { Product Spectrum }\end{array}$ & $\begin{array}{l}\text { Comparison of summer vs winter hits; evaluation of seasonal- } \\
\text { ity }\end{array}$ \\
\hline 18 & Seifter et al, 2010 [66] & Visual evidence & N/A \\
\hline 19 & Sentana-Lledo et al, 2016 [138] & Cosinor analysis & To test the seasonal variations of the Google Trends data \\
\hline 20 & Takada, 2012 [139] & Visual evidence & N/A \\
\hline 21 & Telfer and Woodburn, 2015 [140] & Two-way Wilcoxon signed rank test & To explore differences between winter and summer \\
\hline 22 & Toosi and Kalia, 2015 [142] & Visual evidence; cosinor analysis & To identify differences in seasonality between countries \\
\hline 23 & Willson et al, 2015 [86] & Visual evidence & N/A \\
\hline 24 & Zhang et al, 2015 [71] & Periodograms; ideal pass filter & To study the periodograms; to extract seasonal components \\
\hline
\end{tabular}

${ }^{\mathrm{a}} \mathrm{N} / \mathrm{A}$ : not applicable.

Many studies have employed Google Trends for visualizing the changes in online interest or discussing peaks and spikes [60,62,123,124]. Brigo and Trinka [40] and Brigo et al [39] have studied the search volumes for related terms, Chaves et al [109] and Luckett et al [128] have explored terms related to the studied topic, and Davis et al [110] have examined related internet searches. Other approaches include the reporting of the polynomial trend lines [46] and investigation of statistically significant differences in yearly increases [119]. In addition, "Google Correlate" has been used to explore related terms $[91,138]$.
Finally, several studies have used other sources of big data, namely, Google News [43,63,80], Twitter [43,54,61,63,108], Yandex [52], Baidu [121], Wikipedia [43,63], Facebook and Google+ [54], and YouTube [43,54,63]. Google is the most popular search engine. However, other Web-based sources are used or even preferred to Google in some regions; therefore, many studies use data from these sources to examine general interest in the respective subjects, compare them to Google Trends data, or use them together as variables. 
Table 3. Methods of exploring correlations using Google Trends in health assessment.

\begin{tabular}{|c|c|c|c|}
\hline Number & Authors & Method & Description \\
\hline 1 & Alicino et al, 2015 [85] & Pearson correlation & Ebola-related Google Trends data with Ebola cases \\
\hline 2 & Arora et al, 2016 [81] & Spearman correlation & Suicide search activity vs official suicide rates (and per age) \\
\hline 3 & Bakker et al, 2016 [96] & Correlations & Between Google Trends data and reported cases \\
\hline 4 & Bragazzi et al, 2016 [99] & Pearson correlation & Between Google Trends data and epidemiological data \\
\hline 5 & Bragazzi, 2013 [98] & Autocorrelation; Pearson correlation & $\begin{array}{l}\text { For the time series for multiple sclerosis (MS); between MS } \\
\text { terms }\end{array}$ \\
\hline 6 & Bragazzi et al, 2016 [101] & $\begin{array}{l}\text { Autocorrelation; Partial Autocorrela- } \\
\text { tion }\end{array}$ & To compute correlation of the time series with its own values \\
\hline 7 & Bragazzi et al, 2016 [102] & Pearson correlation & $\begin{array}{l}\text { Status epilepticus terms with etiology and management related } \\
\text { terms }\end{array}$ \\
\hline 8 & Bragazzi et al, 2016 [43] & Pearson correlation & $\begin{array}{l}\text { Google searches for Silicosis with Normalized Google News, } \\
\text { Google Scholar, PubMed Publications, Twitter traffic, } \\
\text { Wikipedia }\end{array}$ \\
\hline 9 & Bragazzi et al, 2016 [63] & Pearson correlation & Among Google Trends data and other data generating sources \\
\hline 10 & Bragazzi, 2014 [103] & $\begin{array}{l}\text { Pearson correlation; autocorrelation } \\
\text { and partial autocorrelation }\end{array}$ & $\begin{array}{l}\text { Nonsuicidal self-injury and related terms; nonsuicidal self- } \\
\text { injury plots showed regular cyclical pattern }\end{array}$ \\
\hline 11 & Cavazos-Regh et al, 2015 [107] & Pearson correlation & $\begin{array}{l}\text { Among Google Trends data for noncigarette tobacco and } \\
\text { prevalence }\end{array}$ \\
\hline 12 & Cho et al, 2013 [78] & Pearson correlation & $\begin{array}{l}\text { Google flu-related queries with surveillance data for different } \\
\text { influenza seasons }\end{array}$ \\
\hline 13 & Crowson et al, 2016 [93] & Pearson correlation & $\begin{array}{l}\text { Between the selected keywords. Between medical prescriptions } \\
\text { data and Google Trends data }\end{array}$ \\
\hline 14 & Deiner et al, 2016 [70] & Spearman correlation & $\begin{array}{l}\text { For correlating seasonality of clinical diagnoses with Google } \\
\text { Trends data }\end{array}$ \\
\hline 15 & Domnich et al, 2015 [79] & Pearson correlation & Among the examined search terms and influenza-like illness \\
\hline 16 & Foroughi et al, 2016 [115] & $\begin{array}{l}\text { Rank correlations; cross-country corre- } \\
\text { lations; Pearson correlations }\end{array}$ & $\begin{array}{l}\text { For search volumes; for the search volumes for cancer; for } \\
\text { the weekly search volumes between countries }\end{array}$ \\
\hline 17 & Gahr et al, 2015 [75] & Pearson correlation & Among annual prescription volumes and Google Trends data \\
\hline 18 & Gamma et al, 2016 [90] & Cross-correlations & Cross-correlations between search volumes and crime statistics \\
\hline 19 & Gollust et al, 2016 [117] & Multinomial Logit Models & To relate health insurance rates \\
\hline 20 & Guernier et al, 2016 [82] & Spearman correlation; cross-correlation & $\begin{array}{l}\text { Correlating the examined search terms with notifications of } \\
\text { tick paralysis cases record; with lag values from }-7 \text { to }+7 \\
\text { months }\end{array}$ \\
\hline 21 & Hassid et al, 2016 [120] & Pearson correlation & $\begin{array}{l}\text { Between Google Trends data and National Inpatient Sample } \\
\text { data }\end{array}$ \\
\hline 22 & Johnson et al, 2014 [84] & Pearson correlation & $\begin{array}{l}\text { Pearson correlations to explore the relation of Google Trends } \\
\text { data and sexually transmitted infection reported rates }\end{array}$ \\
\hline 23 & Kang et al, 2013 [77] & Pearson correlation & $\begin{array}{l}\text { To explore the association of (and among) search terms with } \\
\text { surveillance data }\end{array}$ \\
\hline 24 & Kang et al, 2015 [72] & Spearman correlation & $\begin{array}{l}\text { Google Trends data for allergic rhinitis and related Google } \\
\text { Trends terms and real world epidemiologic data for the United } \\
\text { States }\end{array}$ \\
\hline 25 & Koburger et al, 2015 [65] & Spearman-Brown correlation & $\begin{array}{l}\text { To explore relations among Google Trends data and railway } \\
\text { suicides }\end{array}$ \\
\hline 26 & Ling and Lee, 2016 [126] & Pearson correlation & Between disease prevalence and Google Trends data \\
\hline 27 & Mavragani et al, 2016 [76] & Pearson correlation & $\begin{array}{l}\text { Between Google Trends data and published papers and Google } \\
\text { Trends data with prescriptions }\end{array}$ \\
\hline 28 & Phelan et al, 2016 [133] & Linear Regression & $\begin{array}{l}\text { To examine if there is significant correlation between searches } \\
\text { and time }\end{array}$ \\
\hline
\end{tabular}




\begin{tabular}{|c|c|c|c|}
\hline Number & Authors & Method & Description \\
\hline 29 & Poletto et al, 2016 [56] & Pearson correlation & $\begin{array}{l}\text { Between Google Trends data and number of alerts published } \\
\text { by ProMED mail and the number of Disease Outbreak News } \\
\text { published by the World Health Organization }\end{array}$ \\
\hline 30 & Pollett et al, 2015 [91] & Pearson correlation & To shortlist related search terms to pertussis \\
\hline 31 & Rohart et al, 2016 [135] & $\begin{array}{l}\text { Spearman rank correlations; Spearman } \\
\text { correlation; cross-correlations }\end{array}$ & $\begin{array}{l}\text { For the diseases examined; correlations between diseases and } \\
\text { the investigated search metrics; to identify best lags }\end{array}$ \\
\hline 32 & Shin et al, 2016 [137] & Spearman correlation & $\begin{array}{l}\text { Between Google Trends data and the number of confirmed } \\
\text { cases of Middle East Respiratory Syndrome and for quaran- } \\
\text { tined cases of Middle East Respiratory Syndrome }\end{array}$ \\
\hline 33 & Schootman et al, 2015 [45] & Pearson correlation & $\begin{array}{l}\text { Between Respiratory Syncytial Virus and Behavioral Risk } \\
\text { Factor Surveillance System prevalence data for } 5 \text { cancer } \\
\text { screening tests }\end{array}$ \\
\hline 34 & Schuster et al, 2010 [73] & Correlations & Lipitor Google Trends data and Lipitor revenues \\
\hline 35 & Sentana-Lledo et al, 2016 [138] & Kendall's Tau-b test & $\begin{array}{l}\text { To explore the correlation of Google Trends data with paper } \\
\text { interview survey results }\end{array}$ \\
\hline 36 & Simmering et al, 2014 [50] & Cross-correlations & $\begin{array}{l}\text { Between Google Trends data for drugs and drug utilization, } \\
\text { to see changes in search volumes following knowledge events }\end{array}$ \\
\hline 37 & Solano et al, 2016 [80] & Correlations; cross-correlations & $\begin{array}{l}\text { Between Google Trends data for suicide and national suicide } \\
\text { rates; between different search terms }\end{array}$ \\
\hline 38 & Wang et al, 2015 [92] & Pearson correlation & Between Google Trends data and new dementia cases \\
\hline 39 & Willson et al, 2015 [86] & Spearman correlation & $\begin{array}{l}\text { Between Google Trends data and observed data for aeroaller- } \\
\text { gens }\end{array}$ \\
\hline 40 & Zhang et al, 2015 [71] & Cross-correlations & $\begin{array}{l}\text { To examine linear and temporal associations of the seasonal } \\
\text { data }\end{array}$ \\
\hline 41 & Zhang et al, 2016 [51] & Pearson correlation & $\begin{array}{l}\text { To study pairwise comparisons among searches for different } \\
\text { terms in Google Trends }\end{array}$ \\
\hline
\end{tabular}

Table 4. Forecasting and predictions using Google Trends in health assessment.

\begin{tabular}{|c|c|c|c|}
\hline Number & Authors & Method & Description \\
\hline 1 & Bakker et al, 2016 [96] & Statistical model & $\begin{array}{l}\text { For forecasting chicken poxforce of infection, that is, monthly per } \\
\text { capita rate of infection of children } 0-14\end{array}$ \\
\hline 2 & Domnich et al, 2015 [79] & $\begin{array}{l}\text { Generalized least squares (maximum } \\
\text { likelihood estimates); Holt-Winters }\end{array}$ & $\begin{array}{l}\text { Query-based models to predict influenza-like illness morbidity, with } \\
\text { the exploratory variables: Influenza, Fever, Tachipirin; compared } \\
\text { for forecasting power with Holt-Winters based on the real data (hold } \\
\text { out set) }\end{array}$ \\
\hline 3 & Parker et al, 2016 [132] & Statistical model & For forecasting deaths for 1 year in advance (2015) \\
\hline 4 & Pollett et al, 2015 [91] & Prediction model & $\begin{array}{l}\text { Tested the predicted model with a left-out dataset for prediction ac- } \\
\text { curacy }\end{array}$ \\
\hline 5 & Rohart et al, 2016 [135] & Linear models & To forecast with 1 or 2 weeks step \\
\hline 6 & Solano et al, 2016 [80] & Cross-Correlations & $\begin{array}{l}\text { Forecasting for suicides for } 2 \text { years without data (2013-14) based } \\
\text { on Google Trends data of those years }\end{array}$ \\
\hline 7 & Wang et al, 2015 [92] & Cross-Correlations & To investigate forecasting with lags of $0-12$ months \\
\hline 8 & Zhang et al, 2016 [51] & Autoregressive Moving Average & To predict Respiratory Syncytial Virus for "dabbing" \\
\hline 9 & Zhou et al, 2011 [88] & Dynamic model & $\begin{array}{l}\text { To provide real time estimations by correcting the forecasting with } \\
\text { the new morbidity data when published }\end{array}$ \\
\hline
\end{tabular}


Table 5. Statistical modeling using Google Trends in health assessment.

\begin{tabular}{|c|c|c|c|}
\hline Number & Authors & Method & Description \\
\hline 1 & Alicino et al, 2015 [85] & Multivariate regression & $\begin{array}{l}\text { For relating Ebola Google Trends data, number of Ebola Cases, } \\
\text { and the Human Development Index }\end{array}$ \\
\hline 2 & Bakker et al, 2016 [96] & Statistical model & $\begin{array}{l}\text { For forecasting chicken poxforce of infection, that is, monthly per } \\
\text { capita rate of infection }\end{array}$ \\
\hline \multirow[t]{2}{*}{3} & $\begin{array}{l}\text { Bentley and Ormerod, } 2009 \\
\text { [59] }\end{array}$ & Maximum likelihood estimation & $\begin{array}{l}\text { Established social model for engaging a new behavior for Web- } \\
\text { based searching for flu terms }\end{array}$ \\
\hline & Barnes et al, 2015 [83] & Hierarchical linear modeling & Three levels: 3 Mondays, 6 years, 47 search terms \\
\hline 4 & Bragazzi, 2013 [98] & Multiple linear regression & To confirm multiannual long-term trends \\
\hline 5 & Domnich et al, 2015 [79] & $\begin{array}{l}\text { Generalized linear model, autoregres- } \\
\text { sive moving average process }\end{array}$ & $\begin{array}{l}\text { Query volume-based models to predict influenza-like illness mor- } \\
\text { bidity }\end{array}$ \\
\hline 6 & El-Sheikha, 2015 [113] & Linear regression & $\begin{array}{l}\text { To show the global, regional, and country level interest for the } \\
\text { search term }\end{array}$ \\
\hline 7 & Fenichel et al, 2013 [114] & $\begin{array}{l}\text { Moving average, generalized linear } \\
\text { model }\end{array}$ & Google Trends data as a variable in predicting loses in flights \\
\hline 8 & Garrison et al, 2015 [116] & Seasonal model & Best fit combination of a straight line and a sinusoid \\
\hline 9 & Gollust et al, 2016 [117] & Multinomial logit models & To relate health insurance rates \\
\hline 10 & Haney et al, 2014 [55] & ARIMA $^{\mathrm{a}}$ & Radiology residency interest \\
\hline 11 & Harsha et al, 2014 [68] & Linear model & Statistical justification of annual increase in search volumes \\
\hline 12 & Harsha et al, 2015 [119] & Linear model & $\begin{array}{l}\text { Statistical justification of annual increase in search volumes and } \\
\text { of the Web-based interest related to applications for interventional } \\
\text { radiology }\end{array}$ \\
\hline 13 & Leffler et al, 2010 [125] & Multivariable Linear Regressions & $\begin{array}{l}\text { For studying the effect of climatic and environmental variables to } \\
\text { internet searches }\end{array}$ \\
\hline 17 & Linkov et al, 2014 [46] & Polynomial trend lines & $\begin{array}{l}\text { Fitted spline polynomial trend lines per time without statistical } \\
\text { reporting }\end{array}$ \\
\hline 18 & Liu et al, 2016 [127] & Seasonal model & Best fit combination of a straight line and a sinusoid \\
\hline 19 & Majumder et al, 2016 [129] & Linear Smoothing & To adjust HealthMap to using Google Trends, model fits \\
\hline 20 & Noar et al, 2013 [64] & Linear Regression & $\begin{array}{l}\text { To estimate the slope coefficient for changes in the magnitude of } \\
\text { the effect size of Google Trends data and media search increases }\end{array}$ \\
\hline 21 & Parker et al, 2016[132] & L1-regularization on Google Trends & To build a model for forecasting deaths in each state \\
\hline 22 & Phelan et al, 2014 [49] & Linear Regression & To estimate the relation between news reports and search activity \\
\hline 23 & Phelan et al, 2016 [133] & Linear Regression & $\begin{array}{l}\text { To examine if there is a significant correlation between searches } \\
\text { and time }\end{array}$ \\
\hline 24 & Pollett et al, 2015 [91] & Linear Regression & $\begin{array}{l}\text { Prediction model for pertussis cases based on Google Trends data } \\
\text { of the most related terms }\end{array}$ \\
\hline 25 & Rohart et al, 2016 [135] & Linear models & To forecast with 1 or 2 weeks step \\
\hline 26 & Scatà et al, 2016 [136] & Epidemic model & $\begin{array}{l}\text { Google Trends data is a measure of awareness, along with other } \\
\text { sources }\end{array}$ \\
\hline 27 & Schuster et al, 2010 [73] & Generalized Linear models & $\begin{array}{l}\text { Google Trends data for the examined drugs, Google Trends data } \\
\text { and changes in annual revenues, and Google Trends data vs re- } \\
\text { source utilization }\end{array}$ \\
\hline 28 & Stein et al, 2013 [47] & Regression Fit Lines & To examine differences in queries \\
\hline 29 & $\begin{array}{l}\text { Telfer and Woodburn, } 2015 \\
{[140]}\end{array}$ & Visual decomposition; local regression & $\begin{array}{l}\text { Figures } 4,6 \text { and } 8 \text {; regression-based decomposition of the time } \\
\text { series for the search terms }\end{array}$ \\
\hline 30 & Troelstra et al, 2016 [141] & ARIMA & $\begin{array}{l}\text { To account for dependency between data points in time series for } \\
\text { "quit smoking" searches }\end{array}$ \\
\hline 31 & Willson et al, 2015 [86] & ARIMA & $\begin{array}{l}\text { To quantify the effect of the observed (pollen) counts with the } \\
\text { levels of search activity }\end{array}$ \\
\hline
\end{tabular}




\begin{tabular}{llll}
\hline Number & Authors & Method & Description \\
\hline 32 & Willson et al, 2015 [87] & ARIMA & $\begin{array}{l}\text { To quantify the effect of the observed (pollen) counts with the } \\
\text { levels of search activity }\end{array}$ \\
33 & Yang et al, 2015 [144] & Prediction model (ARGO ${ }^{\mathrm{b}}$ ) & To predict influenza-like illness \\
34 & Zhou et al, 2011 [88] & Dynamic Modeling & For forecasting tuberculosis incidents using Google Trends data \\
\hline
\end{tabular}

aRIMA: autoregressive integrated moving average.

${ }^{\mathrm{b}}$ ARGO: autoregression with Google search data.

Table 6. Statistical tests and tools using Google Trends in health assessment.

\begin{tabular}{|c|c|c|c|}
\hline Number & Authors & Method & Description \\
\hline 1 & Bragazzi et al, 2016 [43] & Mann-Kendall test & $\begin{array}{l}\text { To show the statistical difference of peaks from the remaining } \\
\text { period }\end{array}$ \\
\hline 2 & Bragazzi et al, 2016 [63] & ARIMA $^{\mathrm{a}}$ & $\begin{array}{l}\text { To show increased web searches due to an event, and correct } \\
\text { seasonality }\end{array}$ \\
\hline 3 & Campen et al, 2014 [105] & $\begin{array}{l}\text { Independent samples } t \text { test; Mann- } \\
\text { Whitney U test with Bonferroni correc- } \\
\text { tion }\end{array}$ & $\begin{array}{l}\text { For comparing searches with baseline period; for multiple } \\
\text { weekly data comparisons }\end{array}$ \\
\hline 4 & Crowson et al, 2016 [93] & ANOVA $^{\mathrm{b}}$ (Post-hoc Tukey test) & $\begin{array}{l}\text { To compare grouped geographical federal regions of the } \\
\text { United States (Northeast, Midwest, South, West) }\end{array}$ \\
\hline 5 & El-Sheikha, 2015 [113] & Wilcoxon rank test; Mann-Whitney & $\begin{array}{l}\text { To study the change of interest at different time periods; to } \\
\text { compare Web-based interest between the Northern and } \\
\text { Southern hemispheres }\end{array}$ \\
\hline 6 & Gahr et al, 2015 [75] & Coefficients of determination & $\begin{array}{l}\text { To determine the amount of variability between annual pre- } \\
\text { scription volumes and Google search terms }\end{array}$ \\
\hline 7 & Harsha et al, 2014 [68] & ANOVA (Tukey-Kramer post hot test) & For the comparisons of US regions \\
\hline 8 & Murray et al, 2016 [41] & ANOVA; $t$ test & $\begin{array}{l}\text { To explore differences in months' means per year; for the } \\
\text { statistical differences of peaks compared with the remaining } \\
\text { hits }\end{array}$ \\
\hline 9 & Noar et al, 2013 [64] & Augmented Dickey-Fuller tests & To test for nonstationarity of the time series \\
\hline 10 & Phelan et al, 2014 [49] & ANOVA & To explore differences among countries \\
\hline 11 & Rohart et al, 2016 [135] & Mean Square Error for Prediction & To assess prediction accuracy \\
\hline 12 & Telfer and Woodburn, 2015 [140] & Mann-Kendall trend tests & $\begin{array}{l}\text { To detect trends significantly larger than the variance in the } \\
\text { data for search terms }\end{array}$ \\
\hline 13 & Troelstra et al, 2016 [141] & ARIMA & $\begin{array}{l}\text { Studied the effect of smoking cessation policies with ARIMA } \\
\text { interrupted time series modeling (Multimedia Appendix 1) }\end{array}$ \\
\hline 14 & Zhang et al, 2015 [71] & Augmented Dickey-Fuller test & $\begin{array}{l}\text { To detect whether or not the extracted seasonal components } \\
\text { of the studied trends were stationary }\end{array}$ \\
\hline 15 & Zhang et al, 2016 [51] & ANOVA & $\begin{array}{l}\text { To examine the search interest for dabbing between groups } \\
\text { of legal status states in the United States }\end{array}$ \\
\hline
\end{tabular}

${ }^{\mathrm{a}}$ ARIMA: autoregressive integrated moving average.

${ }^{\mathrm{b}}$ ANOVA: analysis of variance.

\section{Discussion}

\section{Principal Findings}

With internet penetration constantly growing, users' Web-based search patterns can provide a great opportunity to examine and further predict human behavior. In addressing the challenge of big data analytics, Google Trends has been a popular tool in research over the past decade, with its main advantage being that it uses the revealed and not the stated data. Health and medicine are the most popular fields where Google Trends data have been employed so far to examine and predict human behavior. This review provides a detailed overview and classification of the examined studies (109 in total from 2006 through 2016), which are then further categorized and analyzed by approach, method, and statistical tools employed for data analysis. 
Figure 4. The four steps toward employing Google Trends for health assessment.
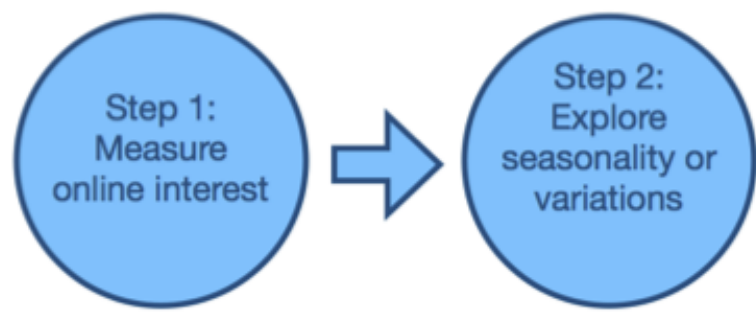

The vast majority of studies using Google Trends in health assessment so far have included data visualization, that is, figures, maps, or screenshots. As discussed in the analysis, the most popular way of using Google Trends data in this field is correlating them with official data on disease occurrence, spreading, and outbreaks. The assessment of suicide tendencies and (prescription or illegal) drug-related queries has been of notably growing popularity over the course of the last years. As is evident, the gap in the existing literature is the use of Google Trends for predictions and forecasting in health-related topics and issues. Though data on reported cases of various health issues and the respective Google Trends data have been correlated in a large number of studies, only a few have proceeded with forecasting incidents and occurrences using online search traffic data.

In research using Google Trends in health and medicine from 2006 to 2016, the ultimate goal is to be able to use and analyze Web-based data to predict and provide insight to better assess health issues and topics. The four main steps, based on the presentation of the papers published up to this point in assessing health using Google Trends, are as follows (Figure 4):

1. Measure the general Web-based interest.

2. Detect any variations or seasonality of Web-based interest, and proceed with examining any relations between actual events or cases.

3. Correlate Web-based search queries among them or with official or actual data and events.

4. Predict, nowcast, and forecast health-related events, outbreaks, etc.

\section{Limitations}

This review followed the Preferred Reporting Items for Systematic Reviews and Meta-Analyses guidelines for selecting the examined papers from the Scopus and PubMed databases.

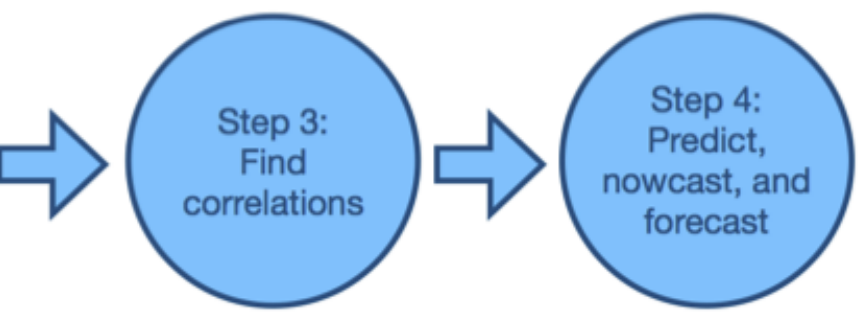

Though this includes the majority of papers published on the topic from 2006 to 2016, the studies that are not indexed in these databases or are not indexed based on the selection criteria used in this review were not included in further analysis. In addition, as is evident in Figure 2, research using Google Trends data has shown a significant increase from each year to the next since 2013. This review included studies published in Google Trends research through 2016. However, there are several studies published in 2017 and 2018 that are not included. This review provides, at first, an overall description of each examined study, which is standard review information. The second part is a classification and assessment of the methodology, tools, and results of each study. Though the first part mainly reports what is included in the methodology of each study, the second part could include a bias, as it is the authors' assessment and categorization of the methods employed based on the results obtained after a very careful and thorough examination of each individual study.

\section{Conclusions}

This review consists of the studies published from 2006 to 2016 on Google Trends research in the Scopus and PubMed databases based on the selected criteria. The aim of this review was to serve as a point of reference for future research in health assessment using Google Trends, as each study, apart from the basic information, for example, period, region, language, is also categorized by the method, approach, and statistical tools employed for the analysis of the data retrieved from Google Trends. Google Trends data are being all the more integrated in infodemiology research, and Web-based data have been shown to empirically correlate with official health data in many topics. It is thus evident that this field will become increasingly popular in the future in health assessment, as the gathering of real time data is crucial in monitoring and analyzing seasonal diseases as well as epidemics and outbreaks.

\section{Conflicts of Interest}

None declared.

\section{Multimedia Appendix 1}

Publication details and categorization.

[PDF File (Adobe PDF File), 256KB-Multimedia Appendix 1]

\section{References}

1. Al Nuaimi E, Al Neyadi H, Mohamed N, Al-Jaroodi J. Applications of big data to smart cities. J Internet Serv Appl 2015 Dec 1;6(1):1-15. [doi: 10.1186/s13174-015-0041-5] 
2. Hilbert M, López P. The world's technological capacity to store, communicate, and compute information. Science 2011 Apr 01;332(6025):60-65 [FREE Full text] [doi: 10.1126/science.1200970] [Medline: 21310967]

3. Philip Chen C, Zhang C. Data-intensive applications, challenges, techniques and technologies: A survey on Big Data. Information Sciences 2014 Aug;275:314-347. [doi: 10.1016/j.ins.2014.01.015]

4. Jin X, Wah BW, Cheng X, Wang Y. Significance and Challenges of Big Data Research. Big Data Research 2015 Jun;2(2):59-64. [doi: 10.1016/j.bdr.2015.01.006]

5. Fosso Wamba S, Akter S, Edwards A, Chopin G, Gnanzou D. How 'big data' can make big impact: Findings from a systematic review and a longitudinal case study. International Journal of Production Economics 2015 Jul;165:234-246. [doi: 10.1016/j.ijpe.2014.12.031]

6. Chang RM, Kauffman RJ, Kwon Y. Understanding the paradigm shift to computational social science in the presence of big data. Decision Support Systems 2014 Jul;63:67-80. [doi: 10.1016/j.dss.2013.08.008]

7. Gandomi A, Haider M. Beyond the hype: Big data concepts, methods, and analytics. International Journal of Information Management 2015 Apr;35(2):137-144. [doi: 10.1016/j.ijinfomgt.2014.10.007]

8. Preis T, Moat HS, Stanley HE, Bishop SR. Quantifying the advantage of looking forward. Sci Rep 2012 Apr;2:350 [FREE Full text] [doi: 10.1038/srep00350] [Medline: 22482034]

9. Preis T, Moat HS, Stanley HE. Quantifying trading behavior in financial markets using Google Trends. Sci Rep 2013 Apr;3:1684 [FREE Full text] [doi: 10.1038/srep01684] [Medline: 23619126]

10. Burnap P, Rana OF, Avis N, Williams M, Housley W, Edwards A, et al. Detecting tension in online communities with computational Twitter analysis. Technological Forecasting and Social Change 2015 Jun;95:96-108. [doi: 10.1016/j.techfore.2013.04.013]

11. Google Trends. URL: https://trends.google.com/trends/explore [accessed 2017-11-08] [WebCite Cache ID 6uot1LkyX]

12. Scharkow M, Vogelgesang J. Measuring the Public Agenda using Search Engine Queries. International Journal of Public Opinion Research 2011 Mar 01;23(1):104-113. [doi: 10.1093/ijpor/edq048]

13. McCallum ML, Bury GW. Public interest in the environment is falling: a response to Ficetola (2013). Biodivers Conserv 2014 Feb 14;23(4):1057-1062. [doi: 10.1007/s10531-014-0640-7]

14. Jun S, Park D. Consumer information search behavior and purchasing decisions: Empirical evidence from Korea. Technological Forecasting and Social Change 2016 Jun;107:97-111. [doi: 10.1016/j.techfore.2016.03.021]

15. Jun S, Park D, Yeom J. The possibility of using search traffic information to explore consumer product attitudes and forecast consumer preference. Technological Forecasting and Social Change 2014 Jul;86:237-253. [doi:

10.1016/j.techfore.2013.10.021]

16. Han S, Chung H, Kang B. It is time to prepare for the future: Forecasting social trends. Communications in Computer and Information Scienc 2012:e2012-e2031.

17. Vosen S, Schmidt T. Forecasting private consumption: survey-based indicators vs. Google trends. J. Forecast 2011 Jan 13;30(6):565-578. [doi: 10.1002/for.1213]

18. Choi H, Varian H. Predicting the Present with Google Trends. Economic Record. (SUPPL.1) 2012;88:2-9. [doi: 10.1111/j.1475-4932.2012.00809.x]

19. Mavragani A, Tsagarakis KP. YES or NO: Predicting the 2015 GReferendum results using Google Trends. Technological Forecasting and Social Change 2016 Aug;109:1-5. [doi: 10.1016/j.techfore.2016.04.028]

20. Carrière-Swallow Y, Labbé F. Nowcasting with Google Trends in an Emerging Market. J. Forecast 2011 Nov 20;32(4):289-298. [doi: 10.1002/for.1252]

21. Vicente MR, López-Menéndez AJ, Pérez R. Forecasting unemployment with internet search data: Does it help to improve predictions when job destruction is skyrocketing? Technological Forecasting and Social Change 2015 Mar;92:132-139. [doi: 10.1016/j.techfore.2014.12.005]

22. Jun S, Yeom J, Son J. A study of the method using search traffic to analyze new technology adoption. Technological Forecasting and Social Change 2014 Jan;81:82-95. [doi: 10.1016/j.techfore.2013.02.007]

23. Google. How Trends data is adjusted URL: https://support.google.com/trends/answer/4365533?hl=en [accessed 2017-11-08] [WebCite Cache ID 6uot8lARg]

24. Fan J, Han F, Liu H. Challenges of Big Data Analysis. Natl Sci Rev 2014 Jun;1(2):293-314 [FREE Full text] [doi: 10.1093/nsr/nwt032] [Medline: 25419469]

25. Yoo C, Ramirez L, Liuzzi J. Big data analysis using modern statistical and machine learning methods in medicine. Int Neurourol J 2014 Jun;18(2):50-57 [FREE Full text] [doi: 10.5213/inj.2014.18.2.50] [Medline: 24987556]

26. Gu D, Li J, Li X, Liang C. Visualizing the knowledge structure and evolution of big data research in healthcare informatics. Int J Med Inform 2017 Dec;98:22-32. [doi: 10.1016/j.ijmedinf.2016.11.006] [Medline: 28034409]

27. Nuti SV, Wayda B, Ranasinghe I, Wang S, Dreyer RP, Chen SI, et al. The use of google trends in health care research: a systematic review. PLoS One 2014 Oct;9(10):e109583 [FREE Full text] [doi: 10.1371/journal.pone.0109583] [Medline: 25337815]

28. Eysenbach G. Infodemiology and infoveillance: framework for an emerging set of public health informatics methods to analyze search, communication and publication behavior on the Internet. J Med Internet Res 2009;11(1):e11 [FREE Full text] [doi: 10.2196/jmir.1157] [Medline: 19329408] 
29. Phillips CA, Barz LA, Li Y, Schapira MM, Bailey LC, Merchant RM. Relationship Between State-Level Google Online Search Volume and Cancer Incidence in the United States: Retrospective Study. J Med Internet Res 2018 Jan 08;20(1):e6 [FREE Full text] [doi: 10.2196/jmir.8870] [Medline: 29311051]

30. Mavragani A, Sampri A, Sypsa K, Tsagarakis KP. Integrating Smart Health in the US Health Care System: Infodemiology Study of Asthma Monitoring in the Google Era. JMIR Public Health Surveill 2018 Mar 12;4(1):e24 [FREE Full text] [doi: 10.2196/publichealth.8726] [Medline: 29530839]

31. Chen T, Dredze M. Vaccine Images on Twitter: Analysis of What Images are Shared. J Med Internet Res 2018 Apr 03;20(4):e130 [FREE Full text] [doi: 10.2196/jmir.8221] [Medline: 29615386]

32. Farhadloo M, Winneg K, Chan MS, Hall JK, Albarracin D. Associations of Topics of Discussion on Twitter With Survey Measures of Attitudes, Knowledge, and Behaviors Related to Zika: Probabilistic Study in the United States. JMIR Public Health Surveill 2018 Feb 09;4(1):e16 [FREE Full text] [doi: 10.2196/publichealth.8186] [Medline: 29426815]

33. Simpson SS, Adams N, Brugman CM, Conners TJ. Detecting Novel and Emerging Drug Terms Using Natural Language Processing: A Social Media Corpus Study. JMIR Public Health Surveill 2018 Jan 08;4(1):e2 [FREE Full text] [doi: 10.2196/publichealth.7726] [Medline: 29311050]

34. van Lent LG, Sungur H, Kunneman FA, van de Velde B, Das E. Too Far to Care? Measuring Public Attention and Fear for Ebola Using Twitter. J Med Internet Res 2017 Jun 13;19(6):e193 [FREE Full text] [doi: 10.2196/jmir.7219] [Medline: 28611015]

35. Wongkoblap A, Vadillo MA, Curcin V. Researching Mental Health Disorders in the Era of Social Media: Systematic Review. J Med Internet Res 2017 Jun 29;19(6):e228 [FREE Full text] [doi: 10.2196/jmir.7215] [Medline: 28663166]

36. Huesch M, Chetlen A, Segel J, Schetter S. Frequencies of Private Mentions and Sharing of Mammography and Breast Cancer Terms on Facebook: A Pilot Study. J Med Internet Res 2017 Jun 09;19(6):e201 [FREE Full text] [doi: 10.2196/jmir.7508] [Medline: 28600279]

37. Lu FS, Hou S, Baltrusaitis K, Shah M, Leskovec J, Sosic R, et al. Accurate Influenza Monitoring and Forecasting Using Novel Internet Data Streams: A Case Study in the Boston Metropolis. JMIR Public Health Surveill 2018 Jan 09;4(1):e4 [FREE Full text] [doi: 10.2196/publichealth.8950] [Medline: 29317382]

38. Roccetti M, Marfia G, Salomoni P, Prandi C, Zagari RM, Gningaye KFL, et al. Attitudes of Crohn's Disease Patients: Infodemiology Case Study and Sentiment Analysis of Facebook and Twitter Posts. JMIR Public Health Surveill 2017 Aug 09;3(3):e51 [FREE Full text] [doi: 10.2196/publichealth.7004] [Medline: 28793981]

39. Brigo F, Igwe SC, Ausserer H, Nardone R, Tezzon F, Bongiovanni LG, et al. Why do people Google epilepsy? An infodemiological study of online behavior for epilepsy-related search terms. Epilepsy Behav 2014 Feb;31:67-70. [doi: 10.1016/j.yebeh.2013.11.020] [Medline: 24361764]

40. Brigo F, Trinka E. Google search behavior for status epilepticus. Epilepsy Behav 2015 Aug;49:146-149. [doi: 10.1016/j.yebeh.2015.02.029] [Medline: 25873438]

41. Murray G, O'Rourke C, Hogan J, Fenton JE. Detecting internet search activity for mouth cancer in Ireland. Br J Oral Maxillofac Surg 2016 Feb;54(2):163-165. [doi: 10.1016/j.bjoms.2015.12.005] [Medline: 26774361]

42. Scheres LJJ, Lijfering WM, Middeldorp S, Cannegieter SC. Influence of World Thrombosis Day on digital information seeking on venous thrombosis: a Google Trends study. J Thromb Haemost 2016 Dec;14(12):2325-2328. [doi: 10.1111/jth.13529] [Medline: 27735128]

43. Bragazzi NL, Dini G, Toletone A, Brigo F, Durando P. Leveraging Big Data for Exploring Occupational Diseases-Related Interest at the Level of Scientific Community, Media Coverage and Novel Data Streams: The Example of Silicosis as a Pilot Study. PLoS One 2016;11(11):e0166051 [FREE Full text] [doi: 10.1371/journal.pone.0166051] [Medline: 27806115]

44. Rosenkrantz AB, Prabhu V. Public Interest in Imaging-Based Cancer Screening Examinations in the United States: Analysis Using a Web-Based Search Tool. AJR Am J Roentgenol 2016 Jan;206(1):113-118. [doi: 10.2214/AJR.15.14840] [Medline: 26700342]

45. Schootman M, Toor A, Cavazos-Rehg P, Jeffe DB, McQueen A, Eberth J, et al. The utility of Google Trends data to examine interest in cancer screening. BMJ Open 2015 Jun 08;5(6):e006678 [FREE Full text] [doi: 10.1136/bmjopen-2014-006678] [Medline: 26056120]

46. Linkov F, Bovbjerg DH, Freese KE, Ramanathan R, Eid GM, Gourash W. Bariatric surgery interest around the world: what Google Trends can teach us. Surg Obes Relat Dis 2014 May;10(3):533-538. [doi: 10.1016/j.soard.2013.10.007] [Medline: 24794184]

47. Stein JD, Childers DM, Nan B, Mian SI. Gauging interest of the general public in laser-assisted in situ keratomileusis eye surgery. Cornea 2013 Jul;32(7):1015-1018 [FREE Full text] [doi: 10.1097/ICO.0b013e318283c85a] [Medline: 23538615]

48. Gafson AR, Giovannoni G. CCSVI-A. A call to clinicans and scientists to vocalise in an Internet age. Mult Scler Relat Disord 2014 Mar;3(2):143-146. [doi: 10.1016/j.msard.2013.10.005] [Medline: 25878001]

49. Phelan N, Kelly JC, Moore DP, Kenny P. The effect of the metal-on-metal hip controversy on Internet search activity. Eur J Orthop Surg Traumatol 2014 Oct;24(7):1203-1210. [doi: 10.1007/s00590-013-1399-3] [Medline: 24390041]

50. Simmering JE, Polgreen LA, Polgreen PM. Web search query volume as a measure of pharmaceutical utilization and changes in prescribing patterns. Res Social Adm Pharm 2014;10(6):896-903. [doi: 10.1016/j.sapharm.2014.01.003] [Medline: 24603135] 
51. Zhang Z, Zheng X, Zeng DD, Leischow SJ. Tracking Dabbing Using Search Query Surveillance: A Case Study in the United States. J Med Internet Res 2016 Sep 16;18(9):e252 [FREE Full text] [doi: 10.2196/jmir.5802] [Medline: 27637361]

52. Zheluk A, Quinn C, Meylakhs P. Internet search and krokodil in the Russian Federation: an infoveillance study. J Med Internet Res 2014 Sep 18;16(9):e212 [FREE Full text] [doi: 10.2196/jmir.3203] [Medline: 25236385]

53. Kadry B, Chu LF, Kadry B, Gammas D, Macario A. Analysis of 4999 online physician ratings indicates that most patients give physicians a favorable rating. J Med Internet Res 2011 Nov;13(4):e95 [FREE Full text] [doi: 10.2196/jmir.1960] [Medline: 22088924]

54. Huesch MD, Currid-Halkett E, Doctor JN. Public hospital quality report awareness: evidence from National and Californian Internet searches and social media mentions, 2012. BMJ Open 2014 Mar 11;4(3):e004417 [FREE Full text] [doi: 10.1136/bmjopen-2013-004417] [Medline: 24618223]

55. Haney NM, Kinsella SD, Morey JM. United States medical school graduate interest in radiology residency programs as depicted by online search tools. J Am Coll Radiol 2014 Feb;11(2):193-197. [doi: 10.1016/j.jacr.2013.06.023] [Medline: 24120904]

56. Poletto C, Boëlle P, Colizza V. Risk of MERS importation and onward transmission: a systematic review and analysis of cases reported to WHO. BMC Infect Dis 2016 Aug 25;16(1):448 [FREE Full text] [doi: 10.1186/s12879-016-1787-5] [Medline: 27562369]

57. Hossain L, Kam D, Kong F, Wigand RT, Bossomaier T. Social media in Ebola outbreak. Epidemiol Infect 2016 Jul;144(10):2136-2143. [doi: 10.1017/S095026881600039X] [Medline: 26939535]

58. Mavragani A, Ochoa G. The Internet and the Anti-Vaccine Movement: Tracking the 2017 EU Measles Outbreak. BDCC 2018 Jan 16;2(1):2. [doi: 10.3390/bdcc2010002]

59. Bentley RA, Ormerod P. Social versus independent interest in 'bird flu' and 'swine flu'. PLoS Curr 2009 Sep 3;1:RRN1036. [doi: 10.1371/currents.RRN1036]

60. Kostkova P, Fowler D, Wiseman S, Weinberg JR. Major infection events over 5 years: how is media coverage influencing online information needs of health care professionals and the public? J Med Internet Res 2013 Jul 15;15(7):e107 [FREE Full text] [doi: 10.2196/jmir.2146] [Medline: 23856364]

61. Pandey A, Abdullah K, Drazner MH. Impact of Vice President Cheney on public interest in left ventricular assist devices and heart transplantation. Am J Cardiol 2014 May 01;113(9):1529-1531. [doi: 10.1016/j.amjcard.2014.02.007] [Medline: 24630787]

62. Brigo F, Lochner P, Tezzon F, Nardone R. Web search behavior for multiple sclerosis: An infodemiological study. Multiple Sclerosis and Related Disorders 2014 Jul;3(4):440-443. [doi: 10.1016/j.msard.2014.02.005]

63. Bragazzi NL, Watad A, Brigo F, Adawi M, Amital H, Shoenfeld Y. Public health awareness of autoimmune diseases after the death of a celebrity. Clin Rheumatol 2016 Dec 20:1911-1917. [doi: 10.1007/s10067-016-3513-5] [Medline: 28000011]

64. Noar S, Ribisl K, Althouse B, Willoughby J, Ayers J. Using digital surveillance to examine the impact of public figure pancreatic cancer announcements on media and search query outcomes. Journal of the National Cancer Institute - Monographs 2013:188-194.

65. Koburger N, Mergl R, Rummel-Kluge C, Ibelshäuser A, Meise U, Postuvan V, et al. Celebrity suicide on the railway network: Can one case trigger international effects? J Affect Disord 2015 Oct 01;185:38-46. [doi: 10.1016/j.jad.2015.06.037] [Medline: 26143403]

66. Seifter A, Schwarzwalder A, Geis K, Aucott J. The utility of "Google Trends" for epidemiological research: Lyme disease as an example. Geospat Health 2010 May;4(2):135-137. [doi: 10.4081/gh.2010.195] [Medline: 20503183]

67. Rossignol L, Pelat C, Lambert B, Flahault A, Chartier-Kastler E, Hanslik T. A method to assess seasonality of urinary tract infections based on medication sales and google trends. PLoS One 2013;8(10):e76020 [FREE Full text] [doi: 10.1371/journal.pone.0076020] [Medline: 24204587]

68. Harsha AK, Schmitt JE, Stavropoulos SW. Know your market: use of online query tools to quantify trends in patient information-seeking behavior for varicose vein treatment. J Vasc Interv Radiol 2014 Jan;25(1):53-57. [doi: 10.1016/j.jvir.2013.09.015] [Medline: 24286941]

69. Ingram DG, Matthews CK, Plante DT. Seasonal trends in sleep-disordered breathing: evidence from Internet search engine query data. Sleep Breath 2015 Mar;19(1):79-84. [doi: 10.1007/s11325-014-0965-1] [Medline: 24595717]

70. Deiner MS, Lietman TM, McLeod SD, Chodosh J, Porco TC. Surveillance Tools Emerging From Search Engines and Social Media Data for Determining Eye Disease Patterns. JAMA Ophthalmol 2016 Sep 01;134(9):1024-1030 [FREE Full text] [doi: 10.1001/jamaophthalmol.2016.2267] [Medline: 27416554]

71. Zhang Z, Zheng X, Zeng DD, Leischow SJ. Information seeking regarding tobacco and lung cancer: effects of seasonality. PLoS One 2015 Mar;10(3):e0117938 [FREE Full text] [doi: 10.1371/journal.pone.0117938] [Medline: 25781020]

72. Kang M, Song W, Choi S, Kim H, Ha H, Kim S, et al. Google unveils a glimpse of allergic rhinitis in the real world. Allergy 2015 Jan;70(1):124-128. [doi: 10.1111/all.12528] [Medline: 25280183]

73. Schuster N, Rogers M, McMahon JL. Using search engine query data to track pharmaceutical utilization: a study of statins. The American journal of managed care 2010;16(8):215-219. 
74. Skeldon SC, Kozhimannil KB, Majumdar SR, Law MR. The effect of competing direct-to-consumer advertising campaigns on the use of drugs for benign prostatic hyperplasia: time series analysis. J Gen Intern Med 2015 Apr;30(4):514-520 [FREE Full text] [doi: 10.1007/s11606-014-3063-y] [Medline: 25338730]

75. Gahr M, Uzelac Z, Zeiss R, Connemann BJ, Lang D, Schönfeldt-Lecuona C. Linking Annual Prescription Volume of Antidepressants to Corresponding Web Search Query Data: A Possible Proxy for Medical Prescription Behavior? J Clin Psychopharmacol 2015 Dec;35(6):681-685. [doi: 10.1097/JCP.0000000000000397] [Medline: 26355849]

76. Mavragani A, Sypsa K, Sampri A, Tsagarakis K. Quantifying the UK Online Interest in Substances of the EU Watchlist for Water Monitoring: Diclofenac, Estradiol, and the Macrolide Antibiotics. Water 2016 Nov 18;8(11):542. [doi: 10.3390/w8110542]

77. Kang M, Zhong H, He J, Rutherford S, Yang F. Using Google Trends for influenza surveillance in South China. PLoS One 2013;8(1):e55205 [FREE Full text] [doi: 10.1371/journal.pone.0055205] [Medline: 23372837]

78. Cho S, Sohn CH, Jo MW, Shin S, Lee JH, Ryoo SM, et al. Correlation between national influenza surveillance data and google trends in South Korea. PLoS One 2013 Dec;8(12):e81422 [FREE Full text] [doi: 10.1371/journal.pone.0081422] [Medline: 24339927]

79. Domnich A, Panatto D, Signori A, Lai PL, Gasparini R, Amicizia D. Age-related differences in the accuracy of web query-based predictions of influenza-like illness. PLoS One 2015;10(5):e0127754 [FREE Full text] [doi: 10.1371/journal.pone.0127754] [Medline: 26011418]

80. Solano P, Ustulin M, Pizzorno E, Vichi M, Pompili M, Serafini G, et al. A Google-based approach for monitoring suicide risk. Psychiatry Res 2016 Dec 30;246:581-586. [doi: 10.1016/j.psychres.2016.10.030] [Medline: 27837725]

81. Arora VS, Stuckler D, McKee M. Tracking search engine queries for suicide in the United Kingdom, 2004-2013. Public Health 2016 Aug;137:147-153. [doi: 10.1016/j.puhe.2015.10.015] [Medline: 26976489]

82. Guernier V, Milinovich GJ, Bezerra SMA, Haworth M, Coleman G, Soares MRJ. Use of big data in the surveillance of veterinary diseases: early detection of tick paralysis in companion animals. Parasit Vectors 2016 Dec 23;9(1):303 [FREE Full text] [doi: 10.1186/s13071-016-1590-6] [Medline: 27215214]

83. Barnes CM, Gunia BC, Wagner DT. Sleep and moral awareness. J Sleep Res 2015 Apr;24(2):181-188 [FREE Full text] [doi: 10.1111/jsr.12231] [Medline: 25159702]

84. Johnson AK, Mehta SD. A comparison of Internet search trends and sexually transmitted infection rates using Google trends. Sex Transm Dis 2014 Jan;41(1):61-63. [doi: 10.1097/OLQ.0000000000000065] [Medline: 24326584]

85. Alicino C, Bragazzi NL, Faccio V, Amicizia D, Panatto D, Gasparini R, et al. Assessing Ebola-related web search behaviour: insights and implications from an analytical study of Google Trends-based query volumes. Infect Dis Poverty 2015 Dec 10;4:54 [FREE Full text] [doi: 10.1186/s40249-015-0090-9] [Medline: 26654247]

86. Willson TJ, Lospinoso J, Weitzel E, McMains K. Correlating Regional Aeroallergen Effects on Internet Search Activity. Otolaryngol Head Neck Surg 2014 Dec 12;152(2):228-232. [doi: 10.1177/0194599814560149] [Medline: 25505261]

87. Willson TJ, Shams A, Lospinoso J, Weitzel E, McMains K. Searching for Cedar: Geographic Variation in Single Aeroallergen Shows Dose Response in Internet Search Activity. Otolaryngol Head Neck Surg 2015 Nov 02;153(5):770-774. [doi: 10.1177/0194599815601650] [Medline: 26340925]

88. Zhou X, Ye J, Feng Y. Tuberculosis surveillance by analyzing Google trends. IEEE Trans Biomed Eng 2011 Aug;58(8):2247-2254. [doi: 10.1109/TBME.2011.2132132] [Medline: 21435969]

89. Fond G, Gaman A, Brunel L, Haffen E, Llorca P. Google Trends $®$ : Ready for real-time suicide prevention or just a Zeta-Jones effect? An exploratory study. Psychiatry Research 2015 Aug;228(3):913-917. [doi:

10.1016/j.psychres.2015.04.022]

90. Gamma A, Schleifer R, Weinmann W, Buadze A, Liebrenz M. Could Google Trends Be Used to Predict Methamphetamine-Related Crime? An Analysis of Search Volume Data in Switzerland, Germany, and Austria. PLoS ONE 2016 Nov 30;11(11):e0166566. [doi: 10.1371/journal.pone.0166566]

91. Pollett S, Wood N, Boscardin WJ, Bengtsson H, Schwarcz S, Harriman K, et al. Validating the Use of Google Trends to Enhance Pertussis Surveillance in California. PLoS Curr 2015 Oct 19:1-10. [doi:

10.1371/currents.outbreaks.7119696b3e7523faa4543faac87c56c2]

92. Wang H, Chen D, Yu H, Chen Y. Forecasting the Incidence of Dementia and Dementia-Related Outpatient Visits With Google Trends: Evidence From Taiwan. J Med Internet Res 2015 Nov 19;17(11):e264 [FREE Full text] [doi: 10.2196/jmir.4516] [Medline: 26586281]

93. Crowson MG, Schulz K, Tucci DL. National Utilization and Forecasting of Ototopical Antibiotics. Otology \& Neurotology 2016;37(8):1049-1054. [doi: 10.1097/MAO.0000000000001115]

94. Scopus. URL: https://www.scopus.com/home.uri [accessed 2017-11-08] [WebCite Cache ID 6uotA2G5x]

95. PubMed. accessed 18/4/2018. URL: https://www.ncbi.nlm.nih.gov/pubmed/ [accessed 2018-09-07] [WebCite Cache ID 72Fb7LRKh]

96. Bakker KM, Martinez-Bakker ME, Helm B, Stevenson TJ. Digital epidemiology reveals global childhood disease seasonality and the effects of immunization. PNAS 2016;113(24):6689 [FREE Full text] [doi: 10.1073/pnas.1523941113] [Medline: 27247405] 
97. Borron SW, Watts SH, Tull J, Baeza S, Diebold S, Barrow A. Intentional Misuse and Abuse of Loperamide: A New Look at a Drug with "Low Abuse Potential". J Emerg Med 2017 Jul;53(1):73-84. [doi: 10.1016/j.jemermed.2017.03.018] [Medline: $\underline{28501383}$

98. Bragazzi NL. Infodemiology and infoveillance of multiple sclerosis in Italy. Mult Scler Int 2013;2013:924029 [FREE Full text] [doi: 10.1155/2013/924029] [Medline: 24027636]

99. Bragazzi NL, Dini G, Toletone A, Brigo F, Durando P. Infodemiological data concerning silicosis in the USA in the period 2004-2010 correlating with real-world statistical data. Data Brief 2017 Feb;10:457-464 [FREE Full text] [doi: 10.1016/j.dib.2016.11.021] [Medline: 28054008]

100. Bragazzi NL, Barberis I, Rosselli R, Gianfredi V, Nucci D, Moretti M, et al. How often people google for vaccination: Qualitative and quantitative insights from a systematic search of the web-based activities using Google Trends. Hum Vaccin Immunother 2017 Feb;13(2):464-469. [doi: 10.1080/21645515.2017.1264742] [Medline: 27983896]

101. Bragazzi N, Bacigaluppi S, Robba C, Siri A, Canepa G, Brigo F. Infodemiological data of West-Nile virus disease in Italy in the study period 2004-2015. Data Brief 2016:839-845 [FREE Full text]

102. Bragazzi NL, Bacigaluppi S, Robba C, Nardone R, Trinka E, Brigo F. Infodemiology of status epilepticus: A systematic validation of the Google Trends-based search queries. Epilepsy Behav 2016 Feb;55:120-123. [doi: 10.1016/j.yebeh.2015.12.017] [Medline: 26773681]

103. Bragazzi NL. A Google Trends-based approach for monitoring NSSI. Psychol Res Behav Manag 2013 Dec;7:1-8 [FREE Full text] [doi: 10.2147/PRBM.S44084] [Medline: 24376364]

104. Braun T, Harréus U. Medical nowcasting using Google Trends: application in otolaryngology. Eur Arch Otorhinolaryngol 2013 Jul;270(7):2157-2160. [doi: 10.1007/s00405-013-2532-y] [Medline: 23632877]

105. van Campen JS, van Diessen E, Otte WM, Joels M, Jansen FE, Braun KPJ. Does Saint Nicholas provoke seizures? Hints from Google Trends. Epilepsy Behav 2014 Mar;32:132-134. [doi: 10.1016/j.yebeh.2014.01.019] [Medline: 24548849]

106. Carneiro HA, Mylonakis E. Google trends: a web-based tool for real-time surveillance of disease outbreaks. Clin Infect Dis 2009 Nov 15;49(10):1557-1564 [FREE Full text] [doi: 10.1086/630200] [Medline: 19845471]

107. Cavazos-Rehg PA, Krauss MJ, Spitznagel EL, Lowery A, Grucza RA, Chaloupka FJ, et al. Monitoring of non-cigarette tobacco use using Google Trends. Tob Control 2015 May;24(3):249-255 [FREE Full text] [doi: 10.1136/tobaccocontrol-2013-051276] [Medline: 24500269]

108. Cha Y, Stow CA. Mining web-based data to assess public response to environmental events. Environ Pollut 2015 Mar;198:97-99. [doi: 10.1016/j.envpol.2014.12.027] [Medline: 25577650]

109. Chaves JN, Libardi AL, Agostinho-Pesse RS, Morettin M, Alvarenga KDF. Tele-health: assessment of websites on newborn hearing screening in Portuguese Language. Codas 2015 Dec;27(6):526-533 [FREE Full text] [doi: 10.1590/2317-1782/20152014169] [Medline: 26691616]

110. Davis NF, Gnanappiragasam S, Thornhill JA. Interstitial cystitis/painful bladder syndrome: the influence of modern diagnostic criteria on epidemiology and on Internet search activity by the public. Transl Androl Urol 2015 Oct;4(5):506-511 [FREE Full text] [doi: 10.3978/j.issn.2223-4683.2015.06.08] [Medline: 26816850]

111. Fazeli DS, Carlos RC, Hall KS, Dalton VK. Novel data sources for women's health research: mapping breast screening online information seeking through Google trends. Acad Radiol 2014 Sep;21(9):1172-1176 [FREE Full text] [doi: 10.1016/j.acra.2014.05.005] [Medline: 24998689]

112. DeVilbiss E, Lee B. Brief Report: Trends in U.S. National Autism Awareness from 2004 to 2014: The Impact of National Autism Awareness Month. Journal of Autism and Developmental Disorders 2014;44(12):3271-3273. [doi: 10.1007/s10803-014-2160-4] [Medline: 24915931]

113. El-Sheikha J. Global search demand for varicose vein information on the internet. Phlebology 2015 Sep;30(8):533-540. [doi: 10.1177/0268355514542681] [Medline: 24993972]

114. Fenichel EP, Kuminoff NV, Chowell G. Skip the trip: air travelers' behavioral responses to pandemic influenza. PLoS One 2013 Mar;8(3):e58249 [FREE Full text] [doi: 10.1371/journal.pone.0058249] [Medline: 23526970]

115. Foroughi F, Lam AK, Lim MS, Saremi N, Ahmadvand A. "Googling” for Cancer: An Infodemiological Assessment of Online Search Interests in Australia, Canada, New Zealand, the United Kingdom, and the United States. JMIR Cancer 2016 May 04;2(1):e5 [FREE Full text] [doi: 10.2196/cancer.5212] [Medline: 28410185]

116. Garrison SR, Dormuth CR, Morrow RL, Carney GA, Khan KM. Seasonal effects on the occurrence of nocturnal leg cramps: a prospective cohort study. CMAJ 2015 Mar 03;187(4):248-253 [FREE Full text] [doi: 10.1503/cmaj.140497] [Medline: 25623650]

117. Gollust SE, Qin X, Wilcock AD, Baum LM, Barry CL, Niederdeppe J, et al. Search and You Shall Find: Geographic Characteristics Associated With Google Searches During the Affordable Care Act's First Enrollment Period. Med Care Res Rev 2017 Dec;74(6):723-735. [doi: 10.1177/1077558716660944] [Medline: 27457426]

118. Harorli OT, Harorli H. Evaluation of internet search trends of some common oral problems, 2004 to 2014 . Community Dental Health 2014;31(3):188-192. [doi: 10.1922/CDH 3330Harorl?05]

119. Harsha AK, Schmitt JE, Stavropoulos SW. Match day: online search trends reflect growing interest in IR training. J Vasc Interv Radiol 2015 Jan;26(1):95-100. [doi: 10.1016/j.jvir.2014.09.011] [Medline: 25541447] 
120. Hassid BG, Day LW, Awad MA, Sewell JL, Osterberg EC, Breyer BN. Using Search Engine Query Data to Explore the Epidemiology of Common Gastrointestinal Symptoms. Dig Dis Sci 2017 Dec;62(3):588-592. [doi: 10.1007/s10620-016-4384-y] [Medline: 27878646]

121. Huang J, Zheng R, Emery S. Assessing the impact of the national smoking ban in indoor public places in china: evidence from quit smoking related online searches. PLoS One 2013 Jun;8(6):e65577 [FREE Full text] [doi: 10.1371/journal.pone.0065577] [Medline: 23776504]

122. Ingram DG, Plante DT. Seasonal trends in restless legs symptomatology: evidence from Internet search query data. Sleep Med 2013 Dec;14(12):1364-1368. [doi: 10.1016/j.sleep.2013.06.016] [Medline: 24152798]

123. Jha S, Wang Z, Laucis N, Bhattacharyya T. Trends in Media Reports, Oral Bisphosphonate Prescriptions, and Hip Fractures 1996-2012: An Ecological Analysis. J Bone Miner Res 2015 Dec;30(12):2179-2187 [FREE Full text] [doi: 10.1002/jbmr.2565] [Medline: 26018247]

124. Lawson MAC, Lawson MA, Kalff R, Walter J. Google Search Queries About Neurosurgical Topics: Are They a Suitable Guide for Neurosurgeons? World Neurosurg 2016 Jun;90:179-185. [doi: 10.1016/j.wneu.2016.02.045] [Medline: 26898496]

125. Leffler CT, Davenport B, Chan D. Frequency and seasonal variation of ophthalmology-related internet searches. Can J Ophthalmol 2010 Jun;45(3):274-279. [doi: 10.3129/i10-022] [Medline: 20436544]

126. Ling R, Lee J. Disease Monitoring and Health Campaign Evaluation Using Google Search Activities for HIV and AIDS, Stroke, Colorectal Cancer, and Marijuana Use in Canada: A Retrospective Observational Study. JMIR Public Health Surveill 2016 Oct 12;2(2):e156 [FREE Full text] [doi: 10.2196/publichealth.6504] [Medline: 27733330]

127. Liu F, Allan GM, Korownyk C, Kolber M, Flook N, Sternberg H, et al. Seasonality of Ankle Swelling: Population Symptom Reporting Using Google Trends. Ann Fam Med 2016 Dec;14(4):356-358 [FREE Full text] [doi: 10.1370/afm.1953] [Medline: 27401424]

128. Luckett T, Disler R, Hosie A, Johnson M, Davidson P, Currow D, et al. Content and quality of websites supporting self-management of chronic breathlessness in advanced illness: a systematic review. NPJ Prim Care Respir Med 2016 Dec 26;26:16025 [FREE Full text] [doi: 10.1038/npjpcrm.2016.25] [Medline: 27225898]

129. Majumder MS, Santillana M, Mekaru SR, McGinnis DP, Khan K, Brownstein JS. Utilizing Nontraditional Data Sources for Near Real-Time Estimation of Transmission Dynamics During the 2015-2016 Colombian Zika Virus Disease Outbreak. JMIR Public Health Surveill 2016 Jun 01;2(1):e30 [FREE Full text] [doi: 10.2196/publichealth.5814] [Medline: 27251981]

130. Mattin MJ, Solano-Gallego L, Dhollander S, Afonso A, Brodbelt DC. The frequency and distribution of canine leishmaniosis diagnosed by veterinary practitioners in Europe. Vet J 2014 Jun;200(3):410-419. [doi: 10.1016/j.tvj1.2014.03.033] [Medline: 24767097]

131. Myers L, Jones J, Boesten N, Lancman M. Psychogenic non-epileptic seizures (PNES) on the Internet: Online representation of the disorder and frequency of search terms. Seizure 2016 Aug 01;40:114-122 [FREE Full text]

132. Parker J, Cuthbertson C, Loveridge S, Skidmore M, Dyar W. Forecasting state-level premature deaths from alcohol, drugs, and suicides using Google Trends data. J Affect Disord 2017 Dec 15;213:9-15. [doi: 10.1016/j.jad.2016.10.038] [Medline: 28171770]

133. Phelan N, Davy S, O'Keeffe GW, Barry DS. Googling in anatomy education: Can google trends inform educators of national online search patterns of anatomical syllabi? Anat Sci Educ 2017 Mar;10(2):152-159. [doi: 10.1002/ase.1641] [Medline: 27547967]

134. Plante DT, Ingram DG. Seasonal trends in tinnitus symptomatology: evidence from Internet search engine query data. Eur Arch Otorhinolaryngol 2015 Oct;272(10):2807-2813. [doi: 10.1007/s00405-014-3287-9] [Medline: 25234771]

135. Rohart F, Milinovich GJ, Avril SMR, Lê Cao KA, Tong S, Hu W. Disease surveillance based on Internet-based linear models: an Australian case study of previously unmodeled infection diseases. Sci Rep 2016 Dec 20;6:38522 [ㅌREE Full text] [doi: 10.1038/srep38522] [Medline: 27994231]

136. Scatà M, Di Stefano A, Liò P, La Corte A. The Impact of Heterogeneity and Awareness in Modeling Epidemic Spreading on Multiplex Networks. Sci Rep 2016 Dec 16;6:37105 [FREE Full text] [doi: 10.1038/srep37105] [Medline: 27848978]

137. Shin S, Seo D, An J, Kwak H, Kim S, Gwack J, et al. High correlation of Middle East respiratory syndrome spread with Google search and Twitter trends in Korea. Sci Rep 2016 Sep 06;6:32920 [FREE Full text] [doi: 10.1038/srep32920] [Medline: 27595921]

138. Sentana-Lledo D, Barbu CM, Ngo MN, Wu Y, Sethuraman K, Levy MZ. Seasons, Searches, and Intentions: What The Internet Can Tell Us About The Bed Bug (Hemiptera: Cimicidae) Epidemic. J Med Entomol 2016 Jan;53(1):116-121. [doi: 10.1093/jme/tjv158] [Medline: 26474879]

139. Takada K. Japanese Interest in "Hotaru" (Fireflies) and "Kabuto-Mushi" (Japanese Rhinoceros Beetles) Corresponds with Seasonality in Visible Abundance. Insects 2012 Apr 10;3(2):424-431 [FREE Full text] [doi: 10.3390/insects3020424] [Medline: 26466535]

140. Telfer S, Woodburn J. Let me Google that for you: a time series analysis of seasonality in internet search trends for terms related to foot and ankle pain. J Foot Ankle Res 2015 Jul;8:27 [FREE Full text] [doi: 10.1186/s13047-015-0074-9] [Medline: 26146521] 
141. Troelstra SA, Bosdriesz JR, de Boer MR, Kunst AE. Effect of Tobacco Control Policies on Information Seeking for Smoking Cessation in the Netherlands: A Google Trends Study. PLoS One 2016 Feb;11(2):e0148489 [FREE Full text] [doi: 10.1371/journal.pone.0148489] [Medline: 26849567]

142. Toosi B, Kalia S. Seasonal and Geographic Patterns in Tanning Using Real-Time Data From Google Trends. JAMA Dermatol 2016 Feb;152(2):215-217. [doi: 10.1001/jamadermatol.2015.3008] [Medline: 26719968]

143. Warren KE, Wen LS. Measles, social media and surveillance in Baltimore City. J Public Health (Oxf) 2017 Sep 01;39(3):e73-e78. [doi: 10.1093/pubmed/fdw076] [Medline: 27521926]

144. Yang S, Santillana M, Kou SC. Accurate estimation of influenza epidemics using Google search data via ARGO. PNAS 2015;112(47):14473 [FREE Full text] [doi: 10.1073/pnas.1515373112] [Medline: 26553980]

145. Köhler MJ, Springer S, Kaatz M. [On the seasonality of dermatoses: a retrospective analysis of search engine query data depending on the season]. Hautarzt 2014 Sep 14;65(9):814-822. [doi: 10.1007/s00105-014-2848-6] [Medline: 25234631]

146. Orellano PW, Reynoso JI, Antman J, Argibay O. Uso de la herramienta Google Trends para estimar la incidencia de enfermedades tipo influenza en Argentina. Cad. Saúde Pública 2015 Apr;31(4):691-700. [doi: 10.1590/0102-311X00072814]

147. Cjuno J, Taype-Rondan A. Estacionalidad de la cefalea en el hemisferio norte y el hemisferio sur: una aproximación utilizando Google Trends. Rev. méd. Chile 2016 Jul;144(7):947-947. [doi: 10.4067/S0034-98872016000700019]

148. Tejada-Llacsa P. Gaceta Sanitaria. 2016. ¿Qué se busca sobre el aborto en Internet? Una evaluación con Google Trends en Perú URL: https://linkinghub.elsevier.com/retrieve/pii/S0213911116300486 [accessed 2018-09-07] [WebCite Cache ID 72FbxshJz]

149. Yang Y, Zeng Q, Zhao H, Yi J, Li Q, Xia Y. Hepatitis B prediction model based on Google trends. Journal of Shanghai Jiaotong University (Medical Science) 2013;33(2):204-208. [doi: 10.3969/j.issn.1674-8115.2013.02.016]

\title{
Abbreviations \\ ANOVA: analysis of variance \\ ARIMA: autoregressive integrated moving average. \\ MS: multiple sclerosis
}

\author{
Edited by G Eysenbach; submitted 08.11.17; peer-reviewed by A Benis, J Bian, C Fincham; comments to author 15.03.18; revised \\ version received 07.05.18; accepted 21.06.18; published 06.11.18 \\ Please cite as: \\ Mavragani A, Ochoa G, Tsagarakis KP \\ Assessing the Methods, Tools, and Statistical Approaches in Google Trends Research: Systematic Review \\ J Med Internet Res 2018;20(11):e270 \\ URL: https://www.jmir.org/2018/11/e270/ \\ doi: 10.2196/jmir.9366 \\ PMID: 30401664
}

(C)Amaryllis Mavragani, Gabriela Ochoa, Konstantinos P Tsagarakis. Originally published in the Journal of Medical Internet Research (http://www.jmir.org), 06.11.2018. This is an open-access article distributed under the terms of the Creative Commons Attribution License (https://creativecommons.org/licenses/by/4.0/), which permits unrestricted use, distribution, and reproduction in any medium, provided the original work, first published in the Journal of Medical Internet Research, is properly cited. The complete bibliographic information, a link to the original publication on http://www.jmir.org/, as well as this copyright and license information must be included. 